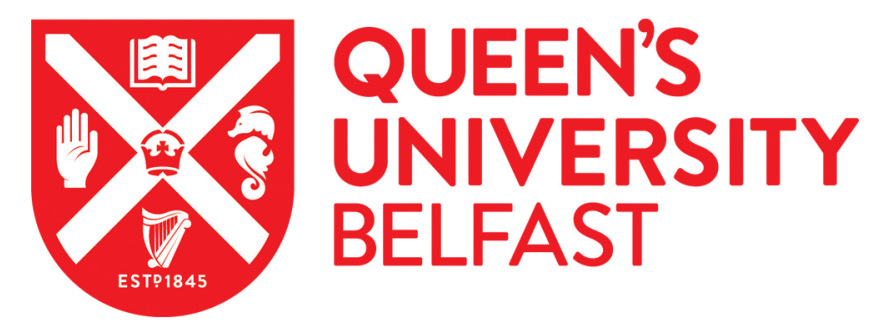

\title{
Effect of pre-treatment and calcination temperature on Al2O3-ZrO2 supported Ni-Co catalysts for dry reforming of methane
}

Al-Fatesh, A., Abu-Dahrieh, J., Atia, H., Armbruster, U., Ibrahim, A. A., Khan, W., Abasaeed, A., \& Fakeeha, A. $\mathrm{H}$. (2019). Effect of pre-treatment and calcination temperature on Al2O3-ZrO2 supported Ni-Co catalysts for dry reforming of methane. International Journal of Hydrogen Energy, 44(39), 21546-21558.

https://doi.org/10.1016/j.ijhydene.2019.06.085

Published in:

International Journal of Hydrogen Energy

Queen's University Belfast - Research Portal:

Link to publication record in Queen's University Belfast Research Portal

\section{General rights}

Copyright for the publications made accessible via the Queen's University Belfast Research Portal is retained by the author(s) and / or other copyright owners and it is a condition of accessing these publications that users recognise and abide by the legal requirements associated with these rights.

Take down policy

The Research Portal is Queen's institutional repository that provides access to Queen's research output. Every effort has been made to ensure that content in the Research Portal does not infringe any person's rights, or applicable UK laws. If you discover content in the Research Portal that you believe breaches copyright or violates any law, please contact openaccess@qub.ac.uk. 
Effect of pre-treatment and calcination temperature on $\mathrm{Al}_{2} \mathrm{O}_{3}-\mathrm{ZrO}_{2}$ supported $\mathrm{Ni}$ Co catalysts for dry reforming of methane

Ahmed Sadeq Al Fatesh ${ }^{\mathrm{a} *}$, Jehad K. Abu-Dahrieh $^{\mathrm{b} *}$, Hanan Atia ${ }^{\mathrm{c}}$, Udo Armbruster $^{\mathrm{c}}$, Ahmed A. Ibrahim ${ }^{a}$, Wasim U. Khan ${ }^{a}$, Ahmed Elhag Abasaeed ${ }^{a}$, Anis H. Fakeeha ${ }^{a}$ ${ }^{\text {a }}$ Chemical Engineering Department, College of Engineering, King Saud University, P.O.

Box 800, Riyadh 11421, Saudi Arabia.

${ }^{\mathrm{b}}$ School of Chemistry and Chemical Engineering, Queen's University Belfast, Belfast BT9 5AG, Northern Ireland, UK.

${ }^{\mathrm{c}}$ Leibniz Institute for Catalysis, Albert-Einstein-Str. 29A, 18059, Rostock, Germany. Corresponding author: Ahmed. Sadeq Al Fatesh, Jehad K. Abu-Dahrieh Email: aalfatesh@ksu.edu.sa ${ }^{1}$, ..abudahrieh@qub.ac.uk ${ }^{2}$ 


\begin{abstract}
In this paper, the effect of pre-treatment and calcination temperature on a series of $5 \% \mathrm{Co} / \mathrm{Al}_{2} \mathrm{O}_{3}-\mathrm{ZrO}_{2}, 5 \% \mathrm{Ni} / \mathrm{Al}_{2} \mathrm{O}_{3}-\mathrm{ZrO}_{2}$ and $2.5 \% \mathrm{Co}-2.5 \% \mathrm{Ni} / \mathrm{Al}_{2} \mathrm{O}_{3}-\mathrm{ZrO}_{2}$ catalysts for dry reforming of methane was investigated. Main focus of our research was to improve the catalyst stability by proper pre-treatment and reaction conditions. The first approach aimed at the catalyst pre-treatment by using bimetallic systems and the second strategy at the in situ suppression of coke. The catalytic activity of bimetallic system was indeed higher compared to the monometallic in the temperature range of $500-800{ }^{\circ} \mathrm{C}$ (space velocity $\left.18000 \mathrm{ml} \cdot \mathrm{h}^{-1} \cdot \mathrm{g}_{\mathrm{cat}}{ }^{-1}, \mathrm{CH}_{4} / \mathrm{CO}_{2}=1\right)$. The bimetallic catalyst calcined at $800{ }^{\circ} \mathrm{C}$ showed highest $\mathrm{CH}_{4}$ conversion without deactivation and gave a $\mathrm{H}_{2} / \mathrm{CO}$ ratio of $91 \%$ and 0.96 , respectively, and good stability with less coke deposition over $28 \mathrm{~h}$ at $800{ }^{\circ} \mathrm{C}$ reaction temperature. This improvement is assigned to the synergism between $\mathrm{Co}$ and $\mathrm{Ni}$, their high dispersion according to interaction with support. It has been shown in our work that pretreatment temperatures and atmospheres have strong impact on stability of the catalyst. TEM, XRD and TPO investigations confirmed that the slight catalyst deactivation was related to the formation of multiwall carbon nanotubes with hollow inner tube structure. The addition of small amounts of steam or oxygen during DRM improved both the catalyst activity and stability as the bimetallic catalyst lost around 9.4\% conversion in DRM, 5.4\% in presence of water and only $3.2 \%$ in presence of $\mathrm{O}_{2}$.
\end{abstract}

Keywords: Bimetallic catalyst, Dry reforming, Methane, Stability, Deactivation, Regeneration 


\section{Introduction}

In recent years industrial processes have been established to convert methane into syngas $\left(\mathrm{H}_{2}, \mathrm{CO}\right)$. Some of these industrial processes comprise steam reforming and partial oxidation while lab-scale studies are also in progress on dry reforming of methane (DRM) and/or a combination of above mentioned processes [1]. The respective equations (Eqs. 13) are stated below. Dry reforming of methane would be attractive as it simultaneously converts main greenhouse gases $\mathrm{CH}_{4}$ and $\mathrm{CO}_{2}$ [2-7]. The produced syngas can be directly used for reactions like hydroformylation or the $\mathrm{H}_{2} / \mathrm{CO}$ ratio can be adjusted for FischerTropsch, dimethyl ether and methanol processes, which require higher $\mathrm{H}_{2} / \mathrm{CO}$ ratios. DRM is usually associated with the reverse water-gas shift reaction Eq. (4).

$$
\begin{array}{lll}
\mathrm{CH}_{4}+\mathrm{H}_{2} \mathrm{O} \rightarrow 3 \mathrm{H}_{2}+\mathrm{CO} \Delta \mathrm{H}^{\circ}=206 \mathrm{~kJ} / \mathrm{mol} & \text { Steam reforming } \\
\mathrm{CH}_{4}+\frac{1}{2} \mathrm{O}_{2} \rightarrow 2 \mathrm{H}_{2}+\mathrm{CO} \Delta \mathrm{H}^{\circ}=-38 \mathrm{~kJ} / \mathrm{mol} & \text { Partial oxidation } \\
\mathrm{CH}_{4}+\mathrm{CO}_{2} \rightarrow 2 \mathrm{H}_{2}+2 \mathrm{CO} \Delta \mathrm{H}^{\circ}=247 \mathrm{~kJ} / \mathrm{mol} & \text { Dry reforming } \\
\mathrm{CO}_{2}+\mathrm{H}_{2} \rightarrow \mathrm{CO}+\mathrm{H}_{2} \mathrm{O} & \Delta \mathrm{H}^{\circ}=37.6 \mathrm{~kJ} / \mathrm{mol} & \text { reverse water-gas shift }
\end{array}
$$

Noble metals display superior performance in this reaction but are generally too expensive [8]. Various emerging catalyst technologies for different applications were also recently reported in the literature [9-17]. Transition metals, for instance Ni and Co, are universally considered as suited catalysts for DRM due to their low costs. On the other hand, they were still not commercialized for DRM because they are prone to rapid deactivation as a consequence of carbon deposition. The following reactions are considered as the main source of coke formation in dry reforming of methane: 
$\mathrm{CH}_{4} \rightarrow 2 \mathrm{H}_{2}+\mathrm{C} \quad \Delta \mathrm{H}^{\circ}=75 \mathrm{~kJ} / \mathrm{mol} \quad$ Methane decomposition

$2 \mathrm{CO} \rightarrow \mathrm{CO}_{2}+\mathrm{C} \quad \Delta \mathrm{H}^{\circ}=-172 \mathrm{~kJ} / \mathrm{mol} \quad$ Boudouard reaction

Both these reactions are limited by thermodynamic equilibrium. At high temperature, Boduouard reaction (Eq. 6) is not significant for coke formation, while methane decomposition (Eq. 5) is favoured.

To tackle the issue of carbon formation, several researchers investigated in depth the nature of the constituents of the catalysts and the operating conditions in order to improve their activity and stability in the process. This was done by supporting the active metals on materials such as alumina [18-22] which has advantages including low cost, great mechanical strength and high surface area. However, the phase transformations and interaction with metals during temperature variation affect and limit its applicability [20]. To solve this issue, alumina can be mixed with other supports to promote the catalyst activity and in general mixed oxide catalysts have better catalytic properties than pure oxides [23-27]. For instance, Bellido et al. [27] tested the effect of mixing $\mathrm{ZrO}_{2}$ and $\mathrm{CaO}$ on the activity of nickel-based catalyst in DRM. They found that the electrical properties, such as particle conductivity as a function of anionic vacancies of the support, have a proportional influence on catalytic activity. The other two approaches to avoid carbon deposition during the reforming of hydrocarbons are to use a high oxygen mobility support or to add basic oxide such as $\mathrm{ZrO}_{2}$ to stabilize the alumina, which facilitates gasification of the carbon simultaneously [5]. Also, Perez-Camacho et al. [5] studied the effect of adding different high oxygen mobility dopants such as $\mathrm{CeO}_{2}, \mathrm{ZrO}_{2}$, or yttrium-stabilised zirconia 
(YSZ) on a Ni perovskite catalyst $\left(\mathrm{Na}_{0.5} \mathrm{La}_{0.5} \mathrm{Ni}_{0.3} \mathrm{Al}_{0.7} \mathrm{O}_{2.5}\right)$. They found that the perovskite doped with $80.9 \% \mathrm{ZrO}_{2}$ and $15.2 \% \mathrm{CeO}_{2}$ gave the lowest amount of carbon deposits.

The pre-treatment conditions of the catalysts play a significant role for the final performance. It has been reported that the activity of supported metal catalysts strongly depends on the thermal treatment (either ex situ or in situ) before reaction, i.e., calcination and reduction temperatures $[28,29]$. Calcination temperature has a substantial effect on dispersion of the active metal particles and the metal-support interaction and therefore influences the rate of carbon formation on the catalyst surface [30]. Wang and Ruckenstein [31] tested the effect of calcination temperature on Co-supported catalysts and found that degree of catalyst reduction and structural properties varied with calcination temperatures, which then altered the catalytic performance. Similarly, the investigation by Sun et al. [32] emphasized the significance of calcination temperature for the development of surface textural properties and phase structure. Our group [33] investigated the effect of combining $\mathrm{Ni}$ and Co metal catalysts and found that the interaction of $\mathrm{Ni}$ and Co gave less carbon formation with higher activity. The importance of calcination temperature on $\mathrm{Ni} / \gamma-\mathrm{Al}_{2} \mathrm{O}_{3}$ catalysts was also studied [28] as well as the effect of reduction temperature on the catalysts using hydrogen. Calcination temperature enhanced the activity while the reduction temperature increased basicity and therefore increased the $\mathrm{CO}_{2}$ adsorption. The enhancement of $\mathrm{CO}_{2}$ adsorption provided more oxygen species on the surface of the catalysts, which increase the gasification of the formed carbon (Eq. 6, back reaction) and prevent carbon deposition.

This paper presents the catalytic performance of a series of $\mathrm{Co}, \mathrm{Ni}$ and $\mathrm{Ni}-\mathrm{Co}$-based catalysts supported on $\mathrm{Al}_{2} \mathrm{O}_{3}-\mathrm{ZrO}_{2}$. The effect of calcination temperature and of different 
catalyst reduction protocols will be discussed. Moreover, the long-term stability of the bimetallic catalyst was examined, and the best-performing catalyst was also tested in presence of small amounts of steam or oxygen to study the impact of feed composition on stability.

\section{Experimental}

\section{Materials}

The chemicals used include cobalt acetate tetrahydrate $\left[\left(\mathrm{CH}_{3} \mathrm{COO}\right)_{2} \mathrm{Co}\right]$, nickel acetate tetrahydrate $\left[\left(\mathrm{CH}_{3} \mathrm{COO}\right)_{2} \mathrm{Ni}\right]$, zirconium butoxide/butylate $\left[\left(\mathrm{OC}_{4} \mathrm{H}_{9}\right)_{4} \mathrm{Zr}\right]$ solution $(80 \mathrm{wt} . \%$ in 1-butanol) and aluminium sec-butoxide/butylate $\left[\left(\mathrm{C}_{12} \mathrm{H}_{27} \mathrm{O}_{3}\right) \mathrm{Al}\right]$ and all were of analytical grade. These chemicals were supplied by Aldrich, UK and Merck.

\section{Catalyst preparation}

In order to get the crystal water-free salts, all the metal precursors were oven dried at 100 ${ }^{\circ} \mathrm{C}$ for $24 \mathrm{~h}$. The weight loss was similar to the water content and therefore no decomposition took place. Prior to use, the salts were ground and sieved below $100 \mu \mathrm{m}$ in order to dissolve and react easily with Al-butylate. These salts were the source for cobalt and nickel. $48 \mathrm{~g}$ of Zr-butylate and $25 \mathrm{~g}$ of Al-sec-butoxide were mixed in a $250 \mathrm{ml}$ threeneck round-bottom glass flask equipped with a reflux cooler and magnetic stirrer. The mixture was subjected to heating under stirring up to $130{ }^{\circ} \mathrm{C}$ followed by addition of 2.59 $\mathrm{g}$ of the dried cobalt acetate. After keeping the mixture under magnetic stirring for $2 \mathrm{~h}$ at $130{ }^{\circ} \mathrm{C}$, the contents in the round-bottom flask were transferred into a $500 \mathrm{ml}$ beaker containing $75 \mathrm{~g}$ of iso-propanol. The residues (butylates) from round-bottom flask were 
poured into another beaker containing $75 \mathrm{~g}$ of iso-propanol. Finally, clear solutions with slightly pink and green colour were obtained for cobalt and nickel, respectively. These solutions were subjected to reflux for $1 \mathrm{~h}$ after addition of $27 \mathrm{~g}$ of distilled water within 1 min under intensive stirring. In order to avoid loss of iso-propanol, a water-containing round-bottom flask was used to cover the beaker. Finally, a glass frit was used to separate precipitate from the liquid after cooling the solution down to room temperature. No washing was necessary. Based on this recipe, three precursors were prepared with $5 \mathrm{wt} \%$ $\mathrm{Ni}, 5 \mathrm{wt} \% \mathrm{Co}$ and $2.5 \mathrm{wt} \% \mathrm{Ni}+2.5 \mathrm{wt} \% \mathrm{Co}$ on the $\mathrm{ZrO}_{2}-\mathrm{Al}_{2} \mathrm{O}_{3}$ support. With each of these precursors, four different pre-treatment protocols were applied (groups 1-4, Table 1). After drying the as-prepared precursor overnight at room temperature, part of the solid was reduced in situ in the DRM reactor with $\mathrm{H}_{2}$ at $800{ }^{\circ} \mathrm{C}$ without preceding calcination (group 1). Another part also was not calcined but reduced ex situ with $\mathrm{H}_{2}$ at $800{ }^{\circ} \mathrm{C}$, transferred to the reactor and reduced in situ with $\mathrm{H}_{2}$ at $800{ }^{\circ} \mathrm{C}$ (group 2). A third part of the sample was heated with $2 \mathrm{~K} / \mathrm{min}$ and calcined ex situ under air at $550{ }^{\circ} \mathrm{C}$ for $6 \mathrm{~h}$, transferred to the reactor and reduced with $\mathrm{H}_{2}$ at $800{ }^{\circ} \mathrm{C}$ (group 3). The last part was heated with $2 \mathrm{~K} / \mathrm{min}$ and calcined ex situ at $800{ }^{\circ} \mathrm{C}$ for $6 \mathrm{~h}$ and subsequently reduced in the reactor with $\mathrm{H}_{2}$ at $800{ }^{\circ} \mathrm{C}$ (group 4). The catalysts were named after the active metals and the respective pretreatment group (Table 1).

Table 1: Overview on pre-treatment protocols and catalyst names. All samples were dried at ambient conditions overnight before pre-treatment

\begin{tabular}{|c|c|c|c|}
\hline Group & Pre-treatment & Catalyst & Name \\
\hline \multirow{3}{*}{1} & \multirow{3}{*}{$\begin{array}{l}\text { - not calcined } \\
\text { - reduced in situ }\left(\mathrm{H}_{2} \text { flow, } 800{ }^{\circ} \mathrm{C}, 1.5 \mathrm{~h}\right)\end{array}$} & $5 \% \mathrm{Co} / \mathrm{ZrO}_{2}-\mathrm{Al}_{2} \mathrm{O}_{3}$ & Co-1 \\
\hline & & $5 \% \mathrm{Ni} / \mathrm{ZrO}_{2}-\mathrm{Al}_{2} \mathrm{O}_{3}$ & Ni-1 \\
\hline & & $2.5 \% \mathrm{Co}+2.5 \% \mathrm{Ni} / \mathrm{ZrO}_{2}-\mathrm{Al}_{2} \mathrm{O}_{3}$ & CoNi-1 \\
\hline \multirow{2}{*}{2} & \multirow{2}{*}{$\begin{array}{l}\text { - not calcined } \\
\text { - reduced ex situ }\left(\mathrm{H}_{2} \text { flow, } 800^{\circ} \mathrm{C}\right)\end{array}$} & $5 \% \mathrm{Co} / \mathrm{ZrO}_{2}-\mathrm{Al}_{2} \mathrm{O}_{3}$ & Co-2 \\
\hline & & $5 \% \mathrm{Ni} / \mathrm{ZrO}_{2}-\mathrm{Al}_{2} \mathrm{O}_{3}$ & $\mathrm{Ni}-2$ \\
\hline
\end{tabular}




\begin{tabular}{|c|l|l|l|}
\hline & - reduced in situ $\left(\mathrm{H}_{2}\right.$ flow, $\left.800{ }^{\circ} \mathrm{C}, 1.5 \mathrm{~h}\right)$ & $2.5 \% \mathrm{Co}+2.5 \% \mathrm{Ni} / \mathrm{ZrO}_{2}-\mathrm{Al}_{2} \mathrm{O}_{3}$ & $\mathrm{CoNi}-2$ \\
\hline \multirow{3}{*}{3} & \multirow{2}{*}{ - calcined (air flow, $\left.550{ }^{\circ} \mathrm{C}, 6 \mathrm{~h}\right)$} & $5 \% \mathrm{Co} / \mathrm{ZrO}_{2}-\mathrm{Al}_{2} \mathrm{O}_{3}$ & $\mathrm{Co}-3$ \\
\cline { 3 - 5 } & - reduced in situ $\left(\mathrm{H}_{2}\right.$ flow, $\left.800{ }^{\circ} \mathrm{C}, 1.5 \mathrm{~h}\right)$ & $5 \% \mathrm{Ni} / \mathrm{ZrO}_{2}-\mathrm{Al}_{2} \mathrm{O}_{3}$ & $\mathrm{Ni}-3$ \\
\cline { 3 - 5 } & & $2.5 \% \mathrm{Co}+2.5 \% \mathrm{Ni} / \mathrm{ZrO}_{2}-\mathrm{Al}_{2} \mathrm{O}_{3}$ & $\mathrm{CoNi}-3$ \\
\hline \multirow{3}{*}{4} & \multirow{3}{*}{- calcined (air flow, $\left.800{ }^{\circ} \mathrm{C}, 6 \mathrm{~h}\right)$} & $5 \% \mathrm{Co} / \mathrm{ZrO}_{2}-\mathrm{Al}_{2} \mathrm{O}_{3}$ & $\mathrm{Co}-4$ \\
\cline { 3 - 5 } & - reduced in situ $\left(\mathrm{H}_{2}\right.$ flow, $\left.800{ }^{\circ} \mathrm{C}, 1.5 \mathrm{~h}\right)$ & $5 \% \mathrm{Ni} / \mathrm{ZrO}_{2}-\mathrm{Al}_{2} \mathrm{O}_{3}$ & $\mathrm{Ni}-4$ \\
\cline { 3 - 5 } & & $2.5 \% \mathrm{Co}+2.5 \% \mathrm{Ni} / \mathrm{ZrO}_{2}-\mathrm{Al}_{2} \mathrm{O}_{3}$ & $\mathrm{CoNi}-4$ \\
\hline
\end{tabular}

\section{Characterization of catalyst}

Micromeritics Tristar II 3020 surface area and porosity analyser was used to evaluate the Brunauer-Emmett-Teller (BET) specific surface area of the catalysts prior to reaction. 0.2 $\mathrm{g}$ of each sample was used for every analysis. Prior to analysis, moisture and other adsorbed gases on the catalysts surface were removed by degassing the samples at $250{ }^{\circ} \mathrm{C}$ for $3 \mathrm{~h}$. Barrett-Joyner-Halenda (BJH) method was adopted to determine the pore size distribution using the corresponding nitrogen adsorption-desorption isotherm.

Temperature-programmed reduction using hydrogen $\left(\mathrm{H}_{2}-\mathrm{TPR}\right)$ and oxidation $\left(\mathrm{O}_{2}-\mathrm{TPO}\right)$ experiments were carried out using Micromeritics AutoChem II apparatus. For each analysis, $70 \mathrm{mg}$ of the sample were pre-treated with Argon $(30 \mathrm{ml} / \mathrm{min})$ for $\mathrm{H}_{2}-\mathrm{TPR}$ and with Helium $\left(30 \mathrm{ml} / \mathrm{min}\right.$ ) for $\mathrm{O}_{2}-\mathrm{TPO}$ at $150{ }^{\circ} \mathrm{C}$ for $30 \mathrm{~min}$. The samples were cooled to ambient temperature before starting the analysis. For $\mathrm{H}_{2}$-TPR, the sample temperature was raised from ambient to $1000{ }^{\circ} \mathrm{C}$ in an automatic furnace under atmospheric pressure. During temperature ramping, $\mathrm{H}_{2} / \mathrm{Ar}$ mixture with a volume ratio 10/90 was flowing at 40 $\mathrm{ml} / \mathrm{min}$ while heating rate was kept constant at $10 \mathrm{~K} / \mathrm{min}$. In $\mathrm{O}_{2}-\mathrm{TPO}$, used for determining the nature of carbon deposits on the spent catalysts, a mixture of $\mathrm{O}_{2}$ and $\mathrm{He}$ was flowing at $30 \mathrm{ml} / \mathrm{min}$ at same rate as in $\mathrm{H}_{2}$-TPR. The outlet gases were monitored by a thermal conductivity detector (TCD) to analyse the hydrogen and oxygen consumption with respect 
to temperature in $\mathrm{H}_{2}-\mathrm{TPR}$ and $\mathrm{O}_{2}-\mathrm{TPO}$ respectively. The amount of carbon deposited during reaction was quantified using Shimadzu thermo-gravimetric analyser. Each spent catalyst with $10-15 \mathrm{mg}$ was subjected to thermal treatment under air from 35 to $1000{ }^{\circ} \mathrm{C}$ (ramp rate of $20 \mathrm{~K} / \mathrm{min}$ ) and carbon contents were calculated.

The crystallinity of catalysts before and after reaction was measured by X-ray powder diffraction (XRD). STADI P automated transmission diffractometer (STOE, Darmstadt) equipped with Ge monochromator and $\mathrm{CuK} \alpha 1$ radiation was used. The patterns were recorded by a STOE position sensitive detector in the $2 \theta$ range of 5 to $70^{\circ}$. The step widths of 0.5 and $100 \mathrm{~s}$ per step were used. Flat plates were used to prepared samples.

The morphology of nano-structured carbon deposited over the catalyst surface was analysed by JEOL JEM-1400 transmission electron microscope (TEM). TEM images were recorded at $120 \mathrm{kV}$ accelerating voltage. Prior to analysis, ultrasonic dispersion of catalyst samples was carried out in ethanol at room temperature. A few drops of the suspension containing catalyst sample were placed on a carbon-coated copper grid. The copper grid was then used for imaging for each sample. The actual amounts of each metal, i.e., Co, Ni, $\mathrm{Zr}$ and $\mathrm{Al}$ were determined using inductively coupled plasma atomic emission spectroscopy (ICP-AES). The results are shown in Table (2).

Table 2: ICP-AES of the prepared catalyst

\begin{tabular}{|c|c|c|c|}
\hline Sample name & Elements & $\begin{array}{c}\text { Theoretical value } \\
\%\end{array}$ & $\begin{array}{c}\text { ICP values } \\
\%\end{array}$ \\
\hline \multirow[t]{3}{*}{$5 \% \mathrm{Co} / \mathrm{Zr}-\mathrm{Al}$} & $\mathrm{Zr}$ & 52 & 48.6 \\
\hline & $\mathrm{Al}$ & 15 & 14.2 \\
\hline & $\mathrm{Co}$ & 5 & 4.5 \\
\hline \multirow[t]{4}{*}{$2.5 \% \mathrm{Co}+2.5 \% \mathrm{Ni} / \mathrm{Zr}-\mathrm{Al}$} & $\mathrm{Zr}$ & 52 & 44.8 \\
\hline & $\mathrm{Al}$ & 15 & 13.6 \\
\hline & $\mathrm{Co}$ & 2.5 & 2.8 \\
\hline & $\mathrm{Ni}$ & 2.5 & 2.6 \\
\hline $5 \% \mathrm{Ni} / \mathrm{Zr}-\mathrm{Al}$ & $\mathrm{Zr}$ & 52 & 45.6 \\
\hline
\end{tabular}




\begin{tabular}{|c|c|c|c|}
\hline & $\mathrm{Al}$ & 15 & 13.1 \\
\cline { 2 - 4 } & $\mathrm{Ni}$ & 5 & 4.4 \\
\hline
\end{tabular}

\section{Catalyst activity}

As-synthesized catalysts (each $0.15 \mathrm{~g}$ ) were tested in a fixed-bed microactivity reactor at atmospheric pressure. The reactor was made up of stainless steel and had an I.D. of $9.4 \mathrm{~mm}$ and was $30 \mathrm{~cm}$ long. A thermocouple was placed in the core of catalyst bed to monitor the reaction temperature. Prior to the DRM test, the metal oxides were reduced to metals with hydrogen $(40 \mathrm{ml} / \mathrm{min})$ at $800{ }^{\circ} \mathrm{C}$ for $90 \mathrm{~min}$ followed by nitrogen purging to remove any residual hydrogen in the reactor. Then the reactor temperature was lowered under flowing nitrogen to set point temperature of $700{ }^{\circ} \mathrm{C}$. The feed gas contained methane and carbon dioxide $(17 \mathrm{ml} / \mathrm{min}$ each) and nitrogen $(11 \mathrm{ml} / \mathrm{min})$ was added as inert. The gas hourly space velocity (GHSV) was $18000 \mathrm{ml} \cdot \mathrm{h}^{-1} \cdot \mathrm{g}_{\text {cat }}{ }^{-1}$ corresponding to a catalyst weight of 0.15 $\mathrm{g}$ and a feed flow rate of $45 \mathrm{ml} / \mathrm{min}$. Reaction temperatures ranged from 500 to $800{ }^{\circ} \mathrm{C}$. Shimadzu 2014 gas chromatograph (GC) was used to analyse gases on-line from the reactor outlet using a thermal conductivity detector (TCD). The GC was equipped with two columns, i.e., Molecular Sieve 5A and Porapak Q for product analysis.

\section{Results and Discussion}

\section{Catalyst characterization}

The XRD patterns for the fresh catalysts are shown in Figure 1a for group 2 (uncalcined + reduced ex situ) and group 4 (calcined at $800{ }^{\circ} \mathrm{C}+$ reduced in situ), respectively. All the catalysts were treated in situ at least once at $800{ }^{\circ} \mathrm{C}$ and have similar patterns in which all the reflections appeared except the one at $45.2^{\circ}$ which only appeared for group 2 catalysts. This reflection can be assigned to metallic Co or Ni according to JCPDS 01-089-7093 and 
JCPDS 03-065-0380 references, respectively. This explains the role of calcination in the dispersion and distribution of the active metal on the support surface.

In group 2, Co and $\mathrm{Ni}$ do not interact with the support and so small reflexes appeared which could stem from $\mathrm{Ni}$, Co and/or Co-Ni alloy, while in group 4 - covering the samples that were calcined at $800{ }^{\circ} \mathrm{C}-\mathrm{Co}$ and $\mathrm{Ni}$ are strongly interacting with the support and so no Co and Ni reflexes were observed. The reflections at $2 \theta=35.6,50.9$ and 60.5 are assigned to $\mathrm{ZrO}_{2}$ [34] while the signal at $2 \theta=30.5^{\circ}$ is ascribed to $\mathrm{Al}_{0.52} \mathrm{Zr}_{0.48} \mathrm{O}_{1.74}$ according to JCPDS 00-053-0294. Essential changes were observed in the phase composition when the calcination temperature was set to $800{ }^{\circ} \mathrm{C}$ in group 4 , as the reflexes of $\mathrm{ZrO}_{2}$ turned to be more intense due to the formation of tetragonal $\mathrm{ZrO}_{2}$ [35]. Moreover, the intensity of the reflexes of $\mathrm{Al}_{0.52} \mathrm{Zr}_{0.48} \mathrm{O}_{1.74}$ phase increased due to the calcination at $800{ }^{\circ} \mathrm{C}$. Figure $1 \mathrm{~b}$ shows XRD patterns of the spent catalysts after $6 \mathrm{~h}$ on stream at $700{ }^{\circ} \mathrm{C}$, illustrating graphite peaks in the spent catalysts as it is confirmed by TEM as well. These reflexes appear at $26^{\circ}$ for CoNi-2, Ni-2, CoNi-4 and Co-4 and at $43^{\circ}$ for CoNi-4 and Co-4. Moreover, the peak intensities for spent $\mathrm{CoNi}-2$ and $\mathrm{Ni}-2$ catalysts are relatively lower than for the fresh materials, indicating the higher dispersion (lower crystallite size) of the bimetallic sample, which can affect their reducibility as will be discussed later. The same behaviour was also found by others [36, 37]. 

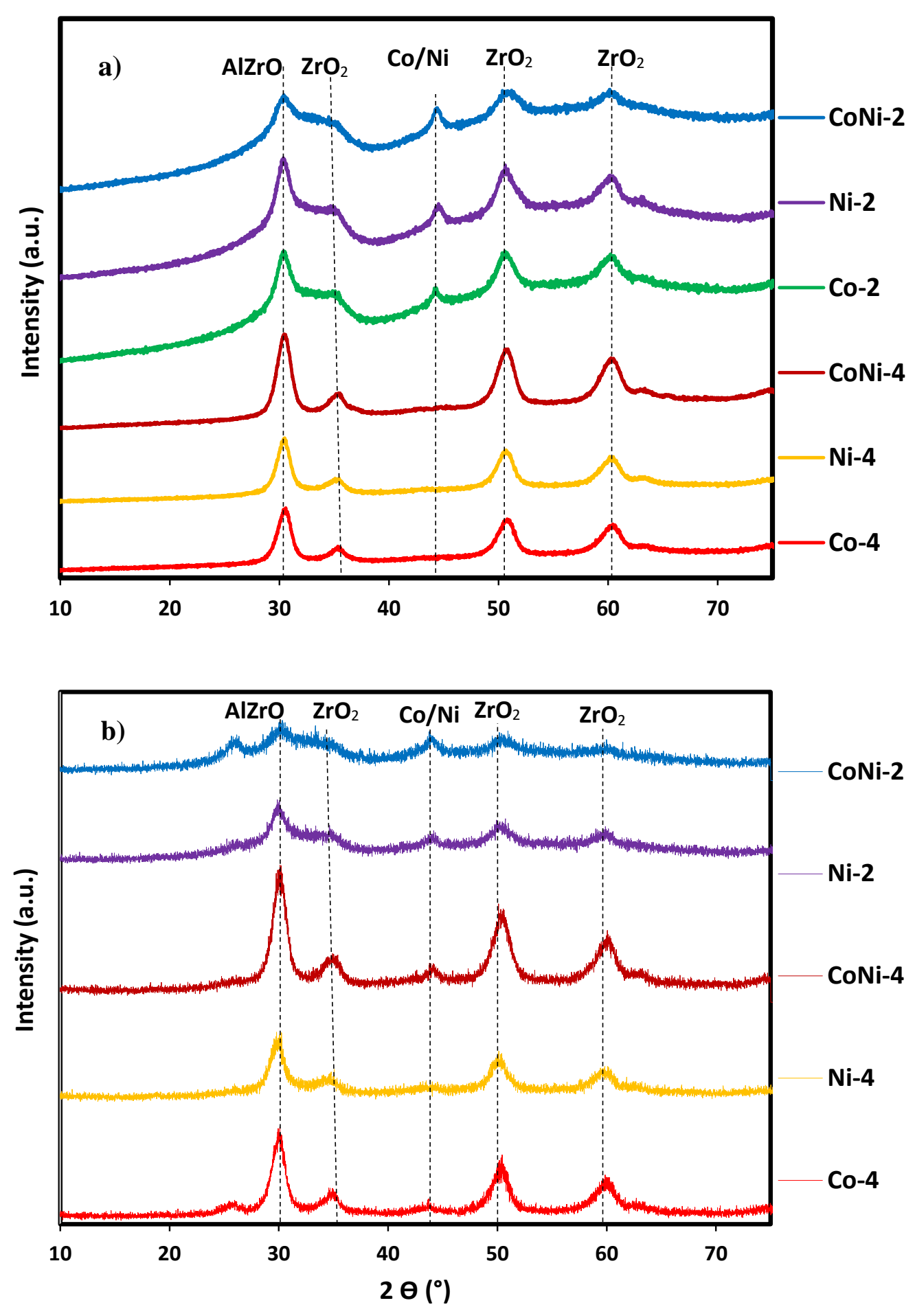

Figure

(1): XRD

patterns of a) fresh catalysts and b) spent catalysts after $6 \mathrm{~h}$ on stream at $700{ }^{\circ} \mathrm{C}$, atmospheric pressure, $\mathrm{CH}_{4}: \mathrm{CO}_{2}=1: 1$ in the feed gas. Catalyst weight: $150 \mathrm{mg}$, WHSV: $18000 \mathrm{ml} \mathrm{g}^{-1} \mathrm{~h}^{-1}$. 
The diffraction pattern of the spent CoNi-4 catalyst after $28 \mathrm{~h}$ on stream at $800^{\circ} \mathrm{C}$ is shown in Figure 2. The new reflection at $2 \theta=26.1^{\circ}$ indicates the formation of graphite $[38,39]$, whereas the reflexes at $2 \theta=43,44.5,53,62$ and $77^{\circ}$ can be assigned to graphite carbon [40].

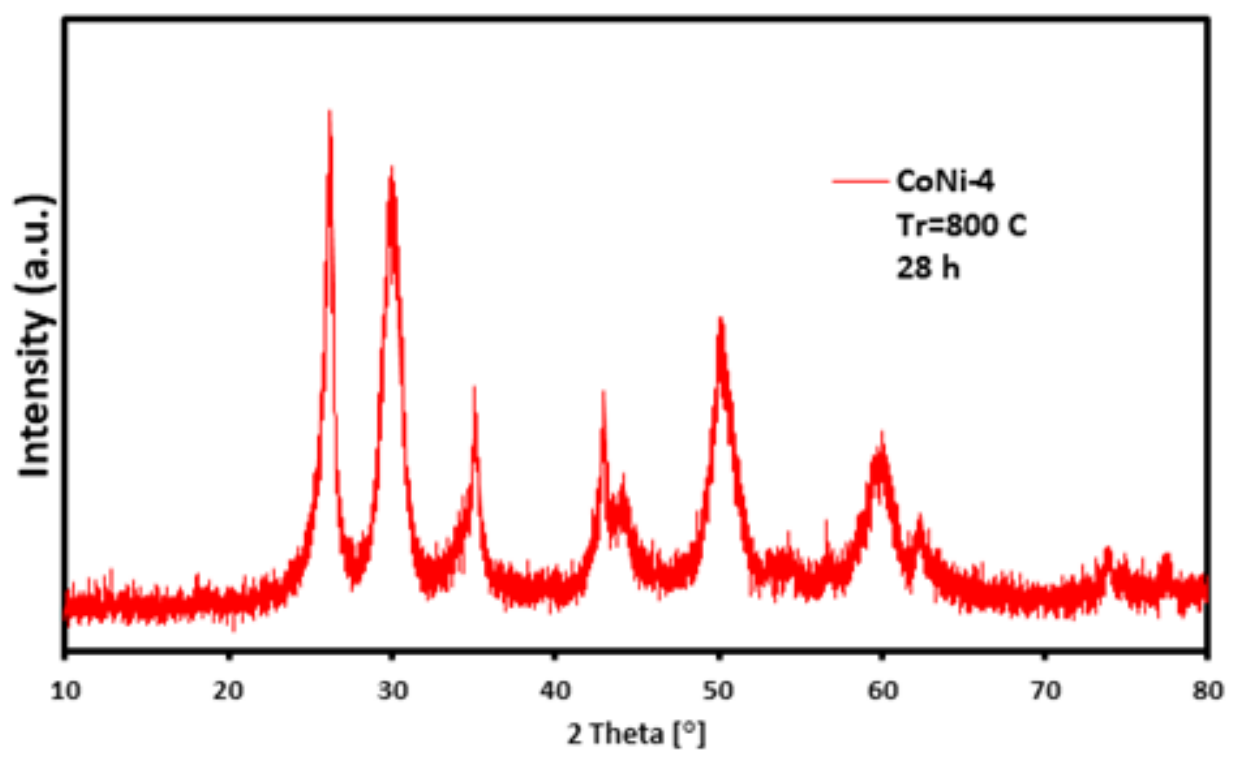

Fig. 2: XRD patterns of spent CoNi-4 catalyst after $28 \mathrm{~h}$ on stream at $800^{\circ} \mathrm{C}$, atmospheric pressure, $\mathrm{CH}_{4} / \mathrm{CO}_{2}=1: 1$. Catalyst was reduced in $\mathrm{H}_{2}$ at $800{ }^{\circ} \mathrm{C}$, catalyst weight $=150 \mathrm{mg}$, WHSV $=18000 \mathrm{ml} \cdot \mathrm{g}^{-1} \cdot \mathrm{h}^{-1}$.

Figures 3-6 display the nitrogen volumes adsorbed with relative pressure for all the catalysts. All the isotherms are categorized as type II, with hysteresis loop similar to $\mathrm{H} 3$ according to IUPAC [41], thus indicating the presence of macropores. Group 1 samples before calcination and/or reduction showed the highest surface area of 384-460 m²/g. The surface area of groups 2,3 , and 4 were in the range of 15-175, 211-216 and 104.7-129.4 $\mathrm{m}^{2} / \mathrm{g}$, respectively. The effect of calcination temperature can be clearly seen on comparing group 3 and 4 . As expected, increasing the calcination temperature of group 4 materials to $800{ }^{\circ} \mathrm{C}$ lead to a decrease in the surface area by $43-50 \%$. This means that high calcination temperature triggers sintering and reduction of surface area and thus particle growth. The 
effect of pretreatment atmosphere can be elucidated by comparing groups 2 and 4 . The loss in surface area of group 4 in comparison with group 2 samples was not as high as compared with group $3(32 \%)$. Calcination temperature has a much higher impact on the surface area compared to the nature of pre-treatment atmosphere. Furthermore, the higher surface area found for group 2 materials could be an explanation for the low crystallinity compared to group 4 as confirmed by XRD.

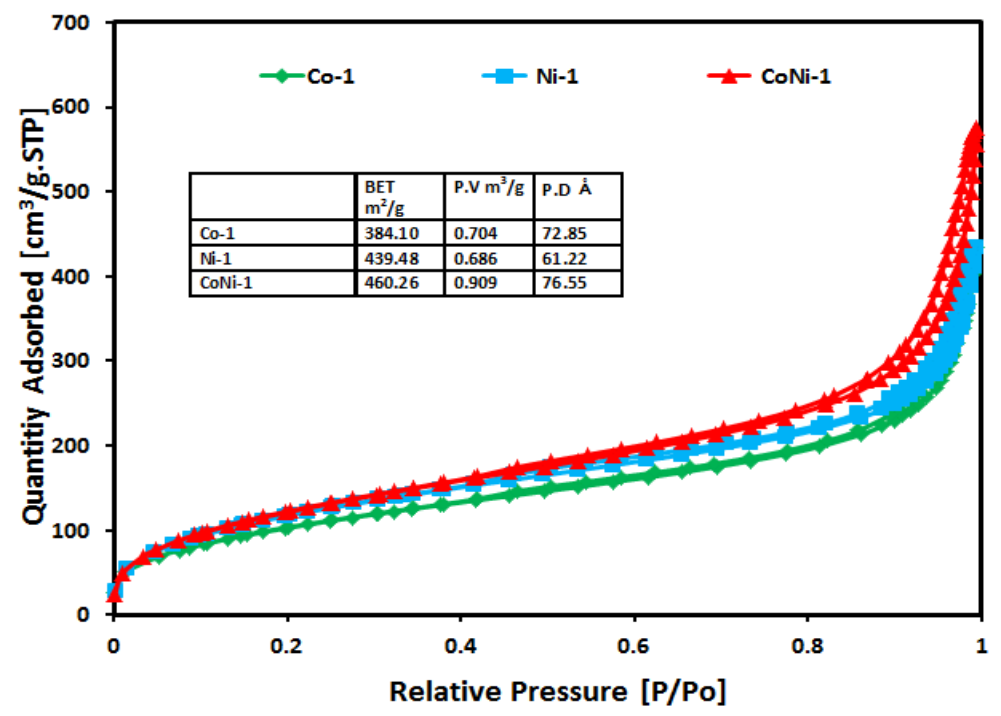

Fig. 3: Adsorption/desorption isotherms, BET pore volumes and pore diameters of group 1 catalysts. 


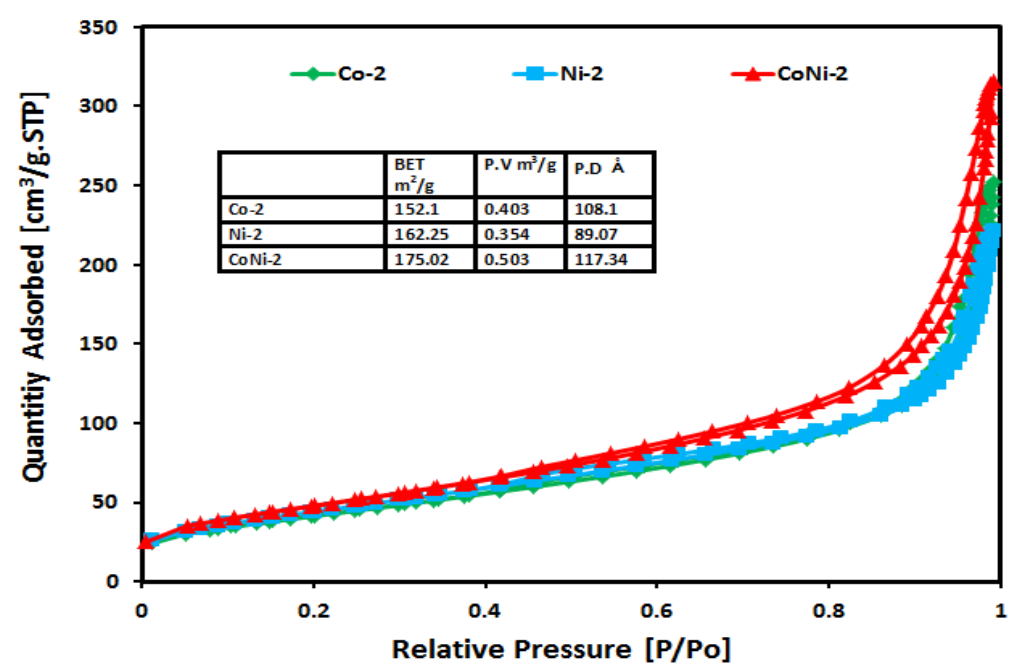

Fig. 4: Adsorption/desorption isotherms, BET pore volumes and pore diameters of group 2 catalysts.

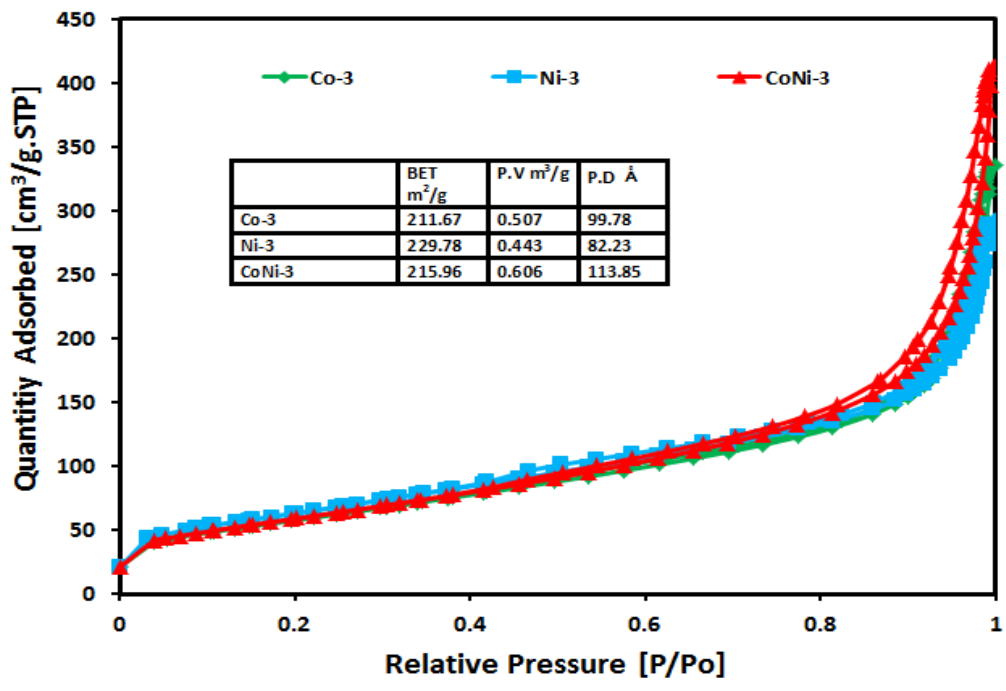

Fig. 5: Adsorption/desorption isotherms, BET pore volumes and pore diameters of group 3 catalysts. 


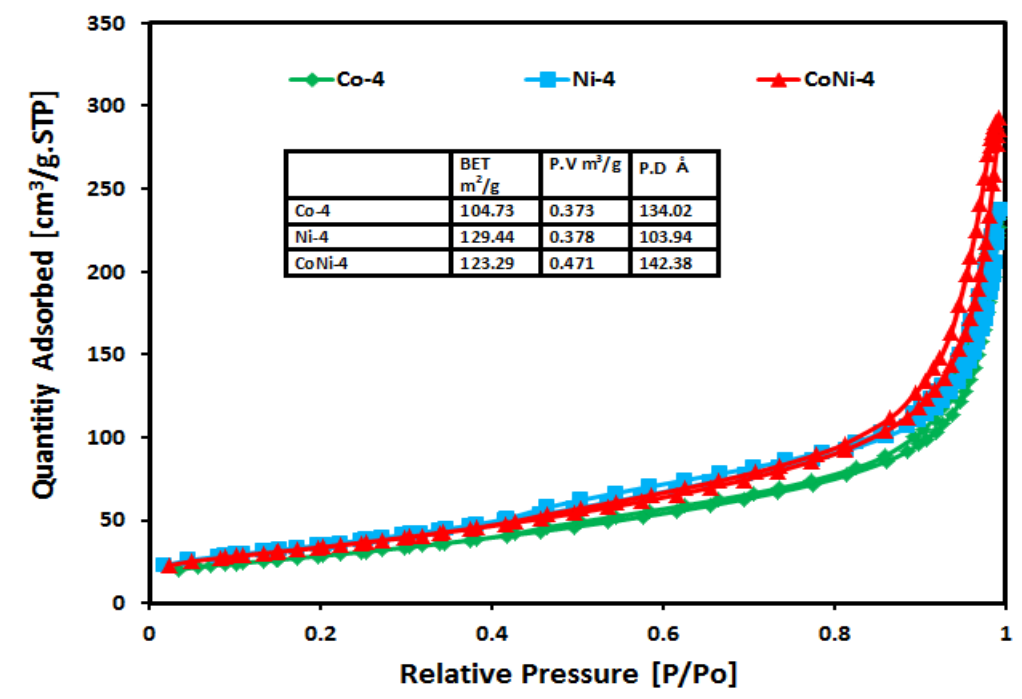

Fig. 6: Adsorption/desorption isotherms, BET pore volumes and pore diameters of group 4 catalysts.

TPR analysis was carried out to determine the catalyst reducibility in respect to the metalsupport interaction. Figures 7-9 summarize the TPR plots of the prepared catalysts, which show only one main reduction peak for each catalyst. Nickel-based catalysts have the lowest reduction temperature as $\mathrm{Ni}$ is much easier to reduce than $\mathrm{Co}$. The high reduction peak temperature for Co-3 and Co-4 catalysts is attributed to the strong interaction between Co and support. For Co-2 the reduction is different from Co-3 and 4. It possesses a peak near $350{ }^{\circ} \mathrm{C}$ which could be assigned to the transition from $\mathrm{Co}^{3+}$ to $\mathrm{Co}^{2+}$, and another shoulder around $470{ }^{\circ} \mathrm{C}$ can be attributed to the reduction of $\mathrm{Co}^{2+}$ to $\mathrm{Co}^{0}$ [42]. Another small peak at $550{ }^{\circ} \mathrm{C}$ which is present in both $\mathrm{Co}-2$ and $\mathrm{Ni}-2$ is due to metal support interaction. The peak of Ni-based catalysts is attributed to the reduction of bulk $\mathrm{NiO}$ to $\mathrm{Ni}^{0}$. Moreover, in all the prepared catalysts, addition of Ni to Co shifts the reduction peak to lower temperature. Low reduction temperature of the bimetallic catalyst is due to the high dispersion as it has been proved by XRD [37]. Setting the calcination temperature to 550 ${ }^{\circ} \mathrm{C}$ (group 3) and to $800{ }^{\circ} \mathrm{C}$ (group 4) shifts reduction temperatures to higher values, 
indicating strong metal-support interaction (Figures 8 and 9) [44, 45]. For instance, the reduction peaks for bimetallic $\mathrm{CoNi}-2$ (not calcined), $\mathrm{CoNi}-3$ (calcined at $550{ }^{\circ} \mathrm{C}$ ) and CoNi-4 (calcined at $800{ }^{\circ} \mathrm{C}$ ) occur at 300,600 and $770{ }^{\circ} \mathrm{C}$, respectively. The peaks for Ni4, CoNi-4 and Co-4 catalysts are centred at 720, 760 and $920{ }^{\circ} \mathrm{C}$, respectively.

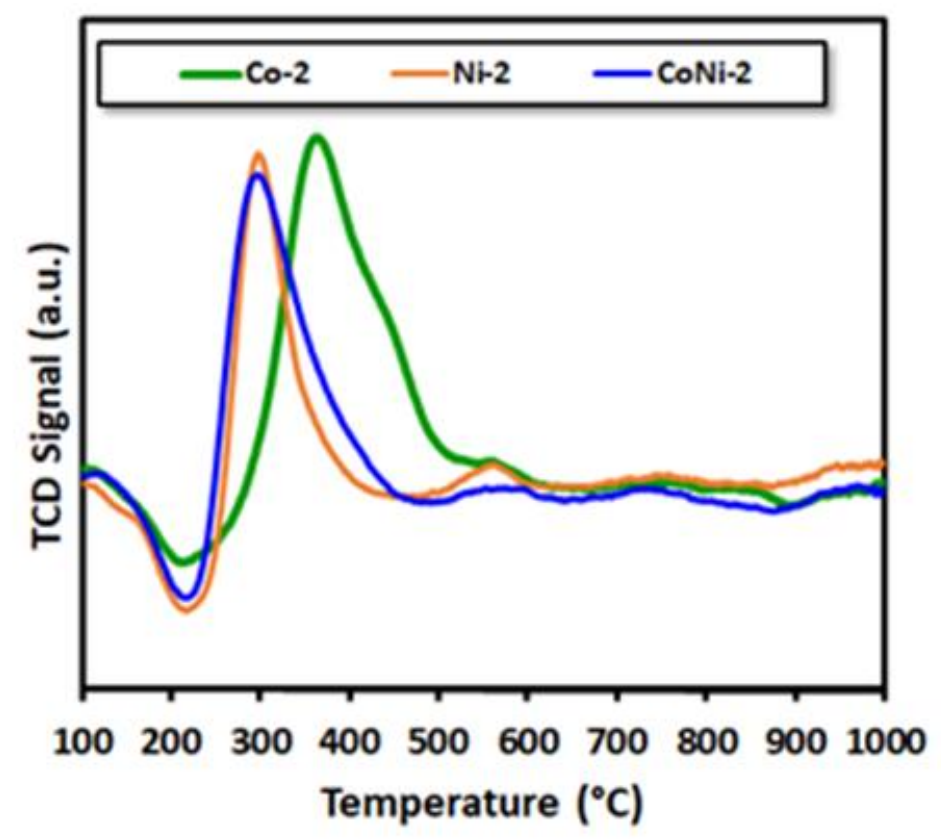

Fig. 7: TPR plots for group 2 catalysts after ex situ reduction at $800{ }^{\circ} \mathrm{C}$. 


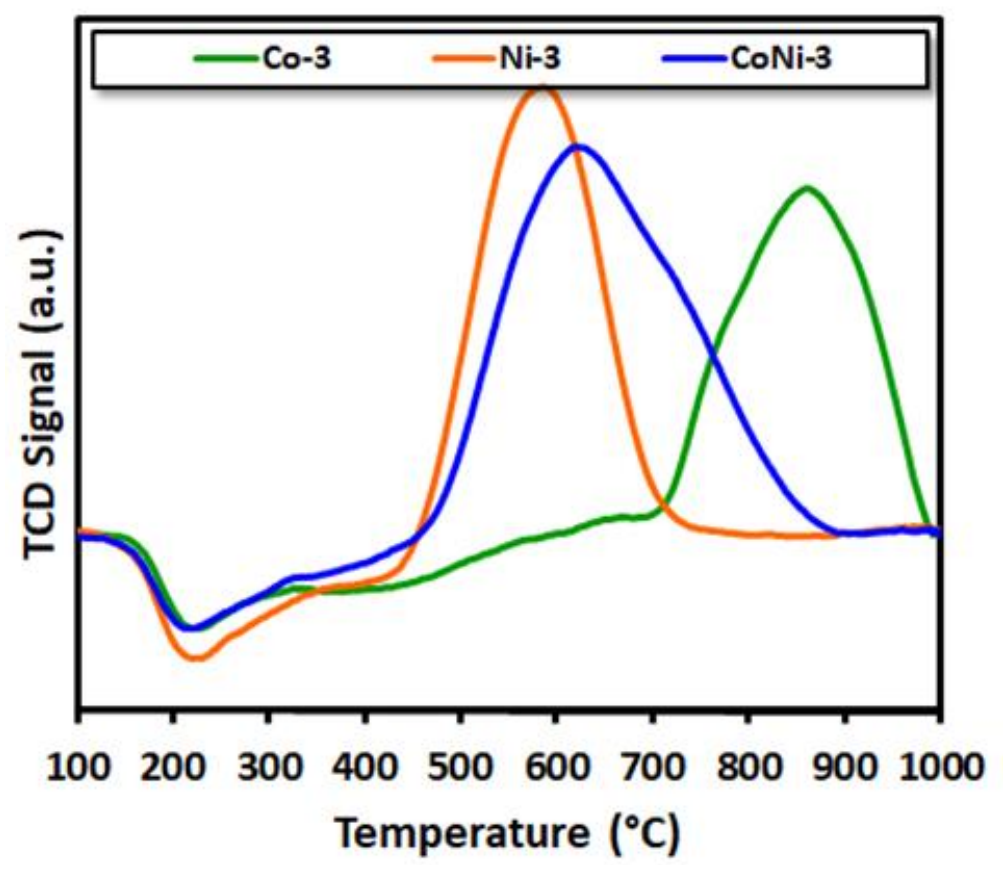

Fig. 8: TPR plots for group 3 catalysts ex situ calcined at $550{ }^{\circ} \mathrm{C}$.

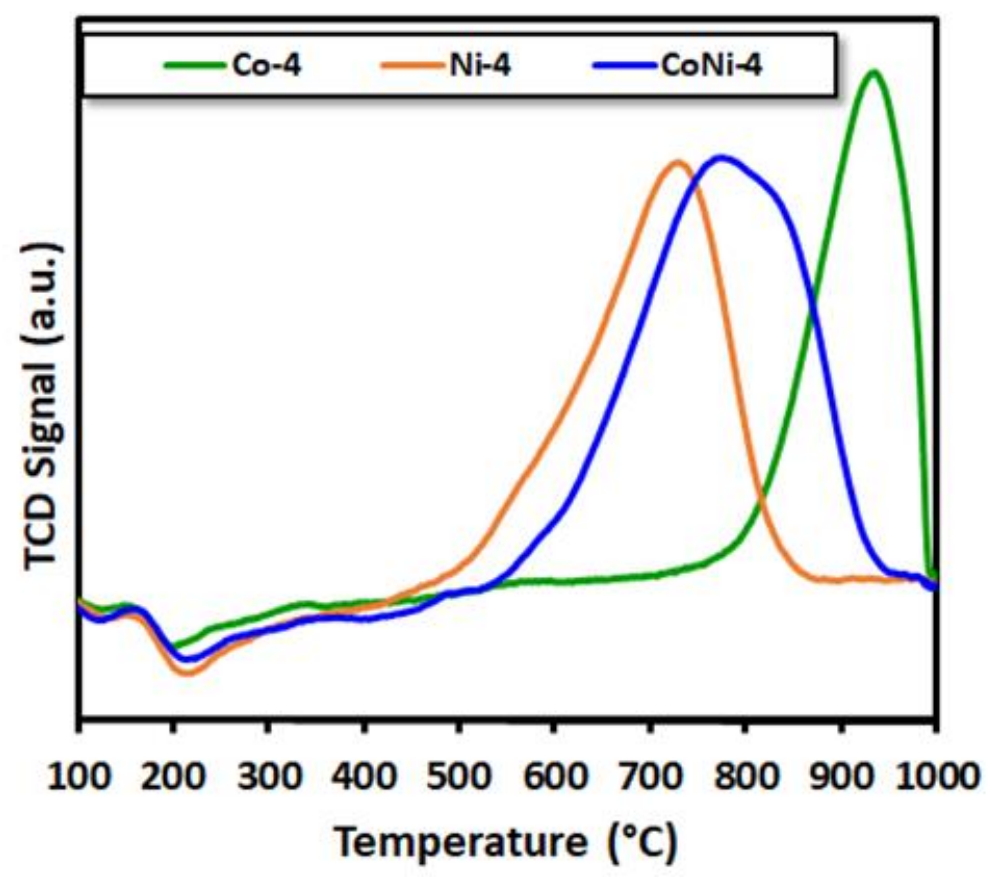

Fig. 9: TPR plots for group 4 catalysts ex situ calcined at $800{ }^{\circ} \mathrm{C}$. 
Table 3 shows the amount of carbon deposits on the surface of the spent catalysts after $6 \mathrm{~h}$ on stream at $700{ }^{\circ} \mathrm{C}$. The carbon deposition on the bimetallic (CoNi-1 and CoNi-2) catalysts is higher than that on the monometallic catalysts.

Table 3: Catalyst activity and amount of carbon deposits from TGA analysis

\begin{tabular}{|c|c|c|c|c|c|c|c|c|}
\hline \multirow[t]{2}{*}{ Group } & \multirow[t]{2}{*}{ Catalyst } & \multicolumn{2}{|c|}{ Conv. $\mathrm{CH}_{4}(\%)$} & \multicolumn{2}{|c|}{ Conv. $\mathrm{CO}_{2}(\%)$} & \multirow{2}{*}{$\begin{array}{c}\text { Avg. } \\
\mathrm{H}_{2} / \mathrm{CO}^{\mathrm{c}}\end{array}$} & \multirow{2}{*}{$\begin{array}{l}\text { D.F. }{ }^{d} \\
(\%)\end{array}$} & \multirow{2}{*}{$\begin{array}{c}\text { Carbon } \\
\text { TGA }^{\mathbf{e}}\end{array}$} \\
\hline & & Initial $^{\mathrm{a}}$ & Final $^{b}$ & Initial $^{\mathrm{a}}$ & Final $^{\text {b }}$ & & & \\
\hline \multirow[t]{3}{*}{1} & Co-1 & 38.2 & 36.8 & 58.2 & 53.0 & 0.67 & 3.66 & 1.65 \\
\hline & $\mathrm{Ni}-1$ & 48.1 & 47.6 & 64.5 & 60.6 & 0.78 & 1.04 & 1.59 \\
\hline & CoNi-1 & 56.6 & 53.5 & 71.3 & 66.3 & 0.82 & 5.50 & 3.97 \\
\hline \multirow[t]{3}{*}{2} & Co-2 & 49.5 & 36.9 & 63.7 & 52.5 & 0.69 & 25.40 & 3.15 \\
\hline & $\mathrm{Ni}-2$ & 67.6 & 63.0 & 74.2 & 69.8 & 0.80 & 6.80 & 6.27 \\
\hline & CoNi-2 & 71.4 & 68.1 & 77.5 & 75.8 & 0.93 & 4.62 & 19.36 \\
\hline \multirow{3}{*}{3} & Co-3 & 44.1 & 45.2 & 65.1 & 60.2 & 0.74 & -2.5 & 1.12 \\
\hline & $\mathrm{Ni}-3$ & 55.5 & 58.7 & 74.5 & 66.6 & 0.86 & -5.8 & 3.51 \\
\hline & CoNi-3 & 51.4 & 51.0 & 65.2 & 64.0 & 0.79 & 0.78 & 1.95 \\
\hline \multirow[t]{3}{*}{4} & Co-4 & 56.8 & 57.4 & 72.1 & 68.5 & 0.86 & -1.1 & 19.75 \\
\hline & $\mathrm{Ni}-4$ & 64.9 & 64.4 & 77.4 & 72.0 & 0.92 & 0.77 & 5.13 \\
\hline & CoNi-4 & 68.5 & 67.3 & 77.4 & 76.3 & 0.91 & 1.80 & 13.21 \\
\hline
\end{tabular}

Reaction condition: $700{ }^{\circ} \mathrm{C}, \mathrm{CH}_{4}+\mathrm{CO}_{2}=34 \mathrm{ml} / \mathrm{min}, \mathrm{N}_{2}=11 \mathrm{ml} / \mathrm{min}$, catalyst wt. $=0.3 \mathrm{~g}$ a) 20 min on stream.

b) Final on stream (360 min).

c) Average data during time-on-stream.

d) Deactivation Factor $($ D.F $)=\left(\right.$ final $\mathrm{CH}_{4}$ conversion - initial conversion $\left.\mathrm{CH}_{4}\right) /($ initial conversion of $\left.\mathrm{CH}_{4}\right) \times 100$.

e) Carbon deposition obtained by TGA method (mg).

Figures 10 and 11 show the TGA profiles for the spent catalysts (CoNi-2 and CoNi-4, respectively) after $6 \mathrm{~h}$ on stream at $500,600,700$ and $800{ }^{\circ} \mathrm{C}$. The reaction temperature has a strong effect on the amount of carbon deposited. Both catalysts CoNi-2 and CoNi-4 have the lowest amount of coke deposited after operation at $800{ }^{\circ} \mathrm{C}$. 


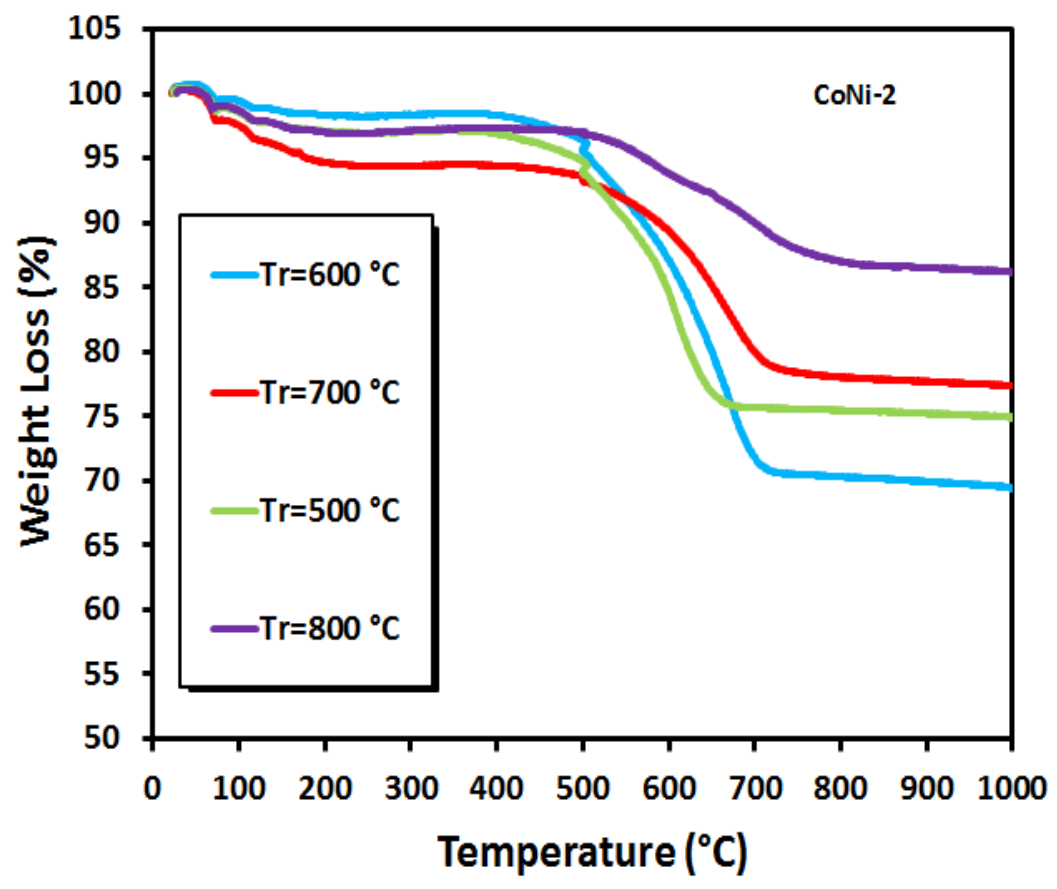

Fig. 10: TGA curves for spent CoNi-2 catalysts from runs at different reaction temperatures, measured in air with heating rate $20 \mathrm{~K} / \mathrm{min}$. 


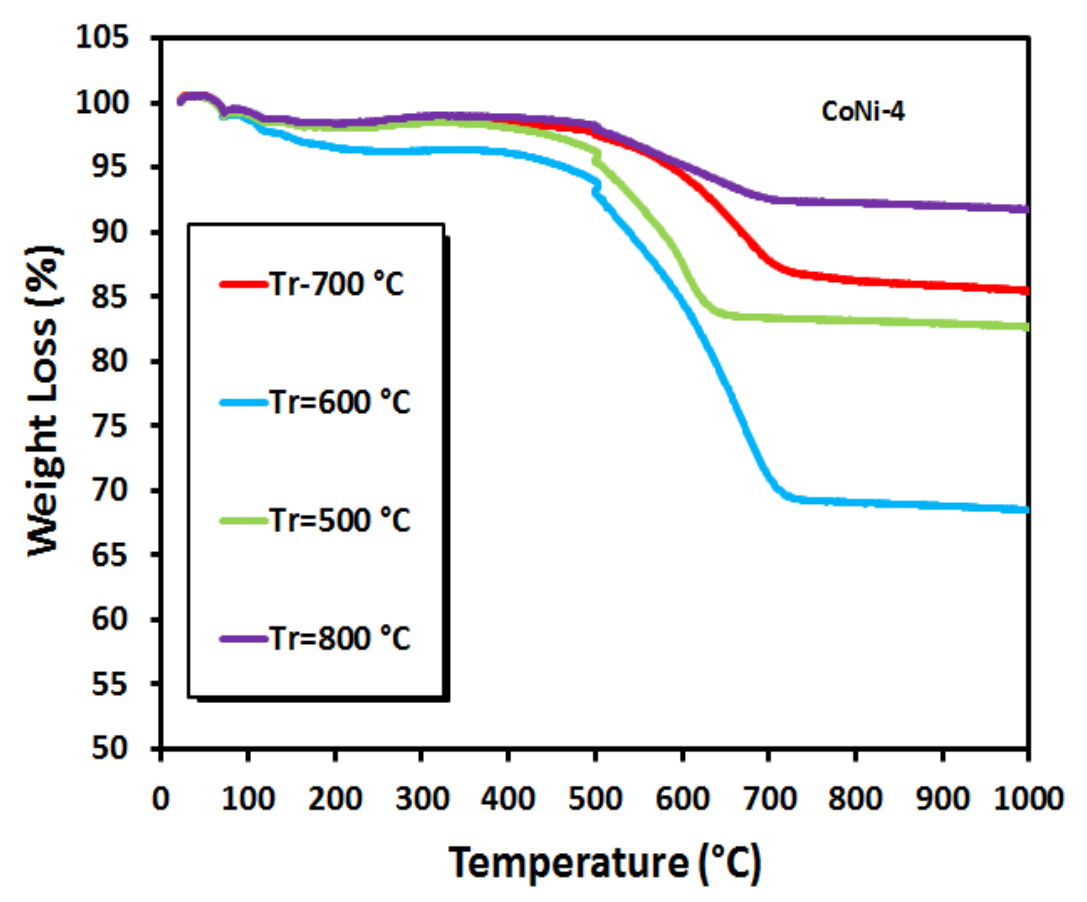

Fig. 11: TGA curves for spent CoNi-4 catalysts from runs at different reaction temperatures, measured in air with heating rate of $20 \mathrm{~K} / \mathrm{min}$.

The TEM analysis of the spent CoNi-4 catalyst after reaction for $28 \mathrm{~h}$ at $800{ }^{\circ} \mathrm{C}$ is shown in Figure 12. The images evidence the formation of multiwall carbon nanotubes of different size together with amorphous carbon. Both ends of the nanotubes were open as seen in Figure 12 a-c. Figure $12 \mathrm{~d}$ shows a carbon nanotube with multiple graphitic layers around the hollow inner tube [38, 39]. 

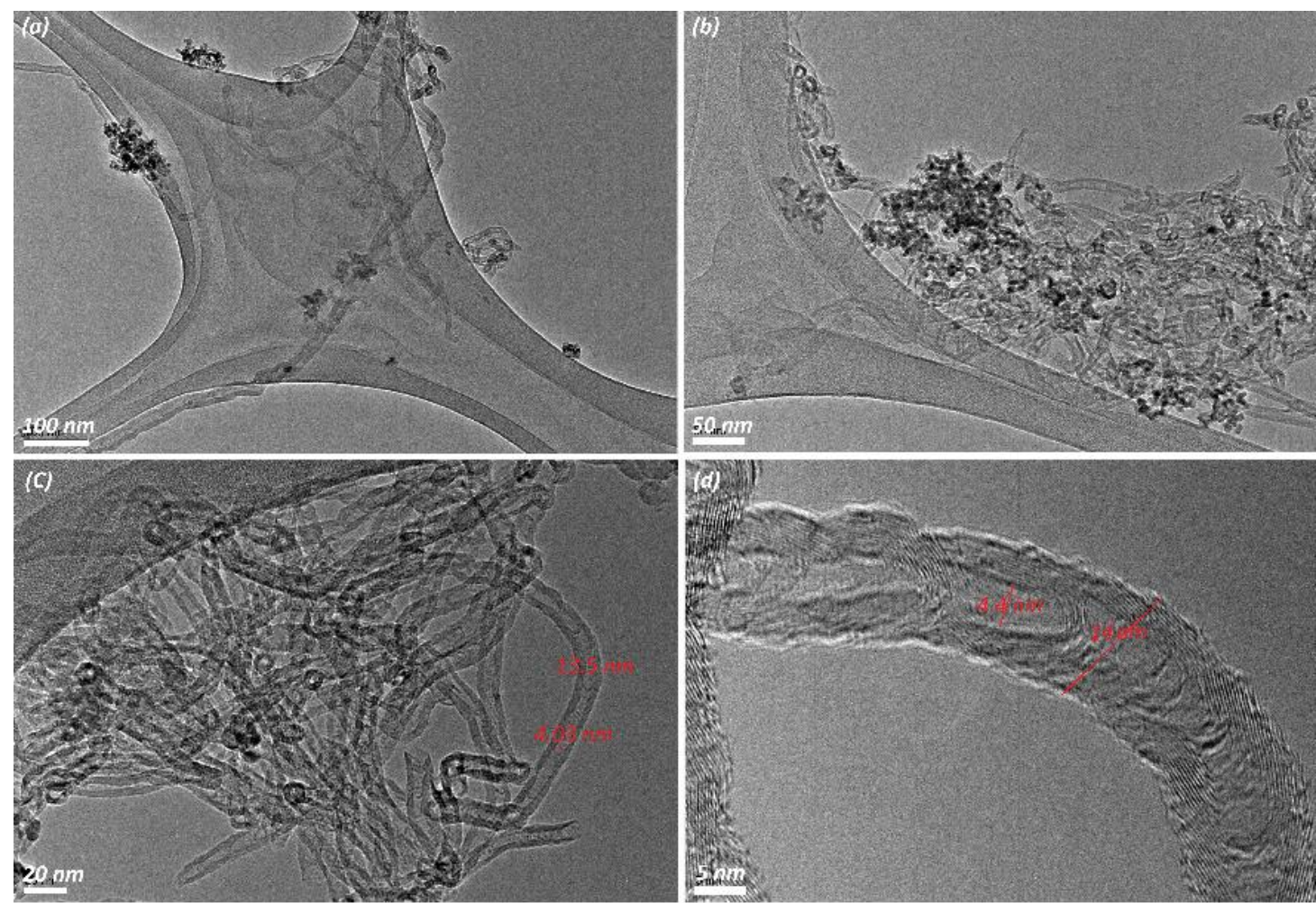

Fig. 12: TEM analysis of the spent CoNi-4 catalyst after reaction for $28 \mathrm{~h}$ at $800{ }^{\circ} \mathrm{C}$, atmospheric pressure, $\mathrm{CH}_{4} / \mathrm{CO}_{2}=1: 1$. Catalyst was reduced in $\mathrm{H}_{2}$ at $800{ }^{\circ} \mathrm{C}$, catalyst weight $=150 \mathrm{mg}$, WHSV $=18000 \mathrm{ml} \cdot \mathrm{g}^{-1} \cdot \mathrm{h}^{-1}$.

Results from TPO study of the nature of carbon deposited on spent CoNi-4 catalysts after $28 \mathrm{~h}$ on stream at $800{ }^{\circ} \mathrm{C}$ and after $6 \mathrm{~h}$ on stream at $700{ }^{\circ} \mathrm{C}$ is shown in Figure 13 . The TPO profile for CoNi-4 after $28 \mathrm{~h}$ showed one shoulder at $620{ }^{\circ} \mathrm{C}$ and another at higher temperature at $720{ }^{\circ} \mathrm{C}$, while the sample after $6 \mathrm{~h}$ on stream shows one peak at $600{ }^{\circ} \mathrm{C}$. This carbonaceous matter can be assigned to multiwall carbon nanotubes (low temperature) and graphite (high temperature). 


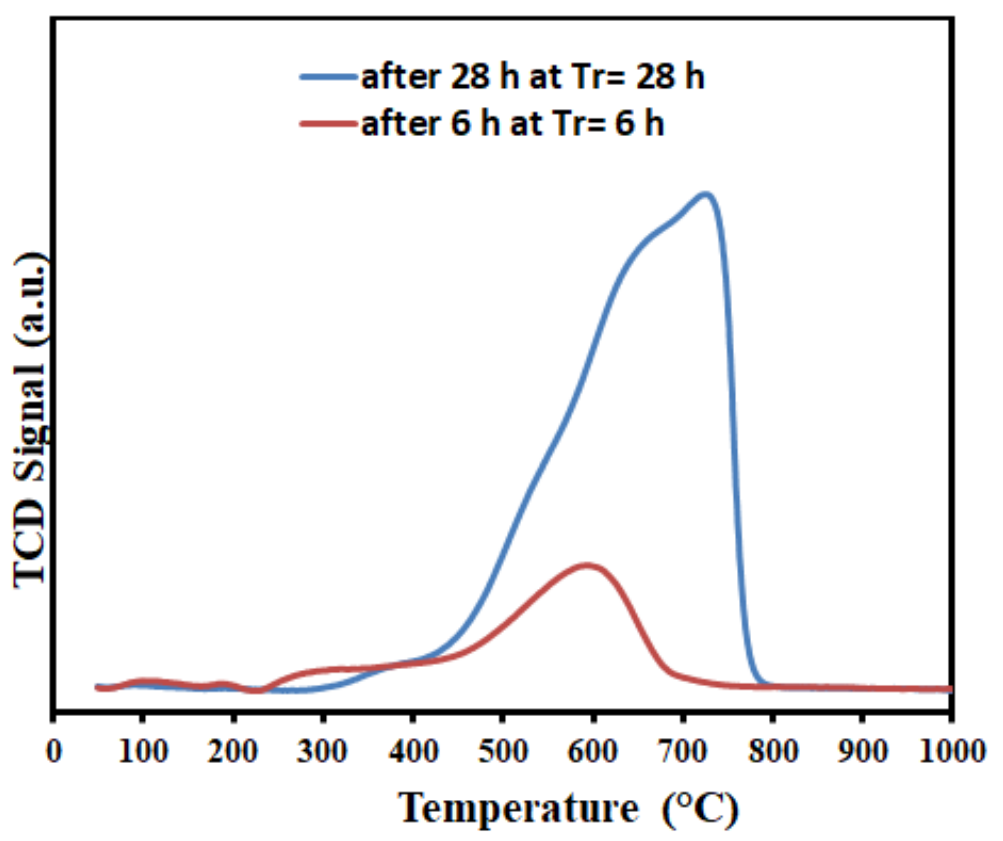

Fig. 13: TPO plots of the spent CoNi-4 catalyst after $28 \mathrm{~h}$ on stream at $800{ }^{\circ} \mathrm{C}$ and after 6 h on stream at $700{ }^{\circ} \mathrm{C}$.

\section{Catalyst Activity}

Table 3 displays the $\mathrm{CO}_{2}$ and $\mathrm{CH}_{4}$ conversions and $\mathrm{H}_{2} / \mathrm{CO}$ ratios in DRM at $700{ }^{\circ} \mathrm{C}$ for all catalysts. The $\mathrm{CH}_{4}$ conversions were always lower than the corresponding $\mathrm{CO}_{2}$ conversions and $\mathrm{H}_{2} / \mathrm{CO}$ ratios were always less than unity in all groups. This phenomenon can be explained by the occurrence of reversed water-gas shift reaction (RWGS, Eq. 2) in which $\mathrm{CO}_{2}$ and $\mathrm{H}_{2}$ are consumed to produce $\mathrm{CO}$ and $\mathrm{H}_{2} \mathrm{O}$ [43].

The table reveals that in all groups the monometallic nickel-based catalyst gives higher $\mathrm{CO}_{2}$ and $\mathrm{CH}_{4}$ conversion than monometallic cobalt-based catalysts. Similar results were found by Gonzalez-de la Cruz [44]. Also, the bimetallic catalysts provide higher $\mathrm{CO}_{2}$ and $\mathrm{CH}_{4}$ conversions than monometallic catalysts. The higher activity of these catalysts can be attributed to the synergistic effect between the Co and Ni metals [40]. Gonzalez-de la Cruz et al. [44] investigated the synergistic effect of $\mathrm{Zr}$-supported bimetallic Ni-Co systems on 
the DRM activity with in-situ X-ray absorption spectroscopy (XAS) and found that even though the monometallic cobalt system is inactive, the $\mathrm{Ni}-\mathrm{Co}$ bimetallic systems have much higher activity and selectivity in DRM as both metals obviously protect each other from oxidation under reaction conditions. $\mathrm{CH}_{4}$ conversions of 49.5, 67.6 and $71.4 \%$ were observed for $\mathrm{Co}-2, \mathrm{Ni}-2$ and $\mathrm{CoNi}-2$ catalysts, respectively. This can be explained by the physical-chemical modification between Co and $\mathrm{Ni}$ (low crystallinity (XRD) and low reduction temperature (TPR)) which has an impact on their activity and stability. The higher the activity of the bimetallic catalysts, the higher the carbon deposition (Table 3). The catalysts CoNi-1, CoNi-2, CoNi-3 and CoNi-4 reached $\mathrm{CH}_{4}$ conversions of 56.6, 71.4, 51.1 and $68.5 \%$ and the analysed carbon amounted to $3.97,19.36,1.95$ and $13.21 \mathrm{mg}$, respectively. For the least active samples Co-1, Co-2, Co-3 and Co-4 the carbon deposits were measured as $1.65,3.15,1.12$ and $19.75 \mathrm{mg}$, respectively. The highest amount of carbon deposition found by sample CoNi-2 could be due to low interaction with the support as it was found by XRD which revealed only small reflexes for $\mathrm{Co}$, Ni or Co-Ni spinel. The carbon deposition can be attributed to both methane decomposition (Eq. 3) and Boudouard reaction (Eq. 4) [46]. Although the carbon deposition on the bimetallic catalysts is high, these catalysts show comparatively high stability in all four groups. This can be attributed to the large pore diameters that are beneficial for the long-term stability as complete pore plugging is hindered. Generally, one reason for the catalyst deactivation could be the carbon deposition within the pores of the catalyst $[47,48]$. The initial conversions of $\mathrm{CH}_{4}$ in the catalysts of groups 4 and 3 are almost the same as the final conversions. However, both groups 1 and 3 showed deactivation and a loss of 5\% in $\mathrm{CH}_{4}$ conversion (deactivation factors of $-1.1,0.77$ and $2.5 \%$ for Co- 4 , Ni-4 and CoNi-4, 
respectively). This indicates that the catalyst pre-treatment has a significant effect on the textural properties and on catalytic activity and stability [28]. To get more information on the nature of carbon deposited on the CoNi-4 catalyst surface after $6 \mathrm{~h}$ on stream at 700 ${ }^{\circ} \mathrm{C}$, TEM images were recorded. As shown in Figure 12, multiwall carbon nanotubes were formed with different diameter and orientation and with high degree of disorder which confirms the contribution of reverse Boudouard reaction (Eq. 4) in which $\mathrm{CO}_{2}$ reacts with any type of deposited carbon [49]. This is in agreement with TPO results. The variation in reaction temperature has been studied over CoNi-2 and CoNi-4. Figures 14 and 15 show the effect of reaction temperature on $\mathrm{CO}_{2}$ and $\mathrm{CH}_{4}$ conversion and $\mathrm{H}_{2} / \mathrm{CO}$ ratio. Again, $\mathrm{CO}_{2}$ conversions are higher than the corresponding $\mathrm{CH}_{4}$ conversions at all reaction temperatures due to RWGS which consumes $\mathrm{CO}_{2}$ as well. Furthermore, these catalysts showed high stability at all reaction temperatures. This can be explained by the synergistic effect between the metals by forming smaller sized bimetallic oxides that are resistant to be oxidised under the reaction conditions. These two bimetallic catalysts $(\mathrm{CoNi}-2$ and CoNi-4) also have the highest pore diameters. The $\mathrm{CH}_{4}$ conversions for $\mathrm{CoNi}-4$ are 15,35 , 69 and $90 \%$ at $500,600,700$ and $800{ }^{\circ} \mathrm{C}$, respectively, with the $\mathrm{H}_{2} / \mathrm{CO}$ ratio approaching unity at $800{ }^{\circ} \mathrm{C}$. The increase in $\mathrm{H}_{2} / \mathrm{CO}$ ratio at high temperature can be explained by an increase of endothermic methane decomposition to carbon and hydrogen. 

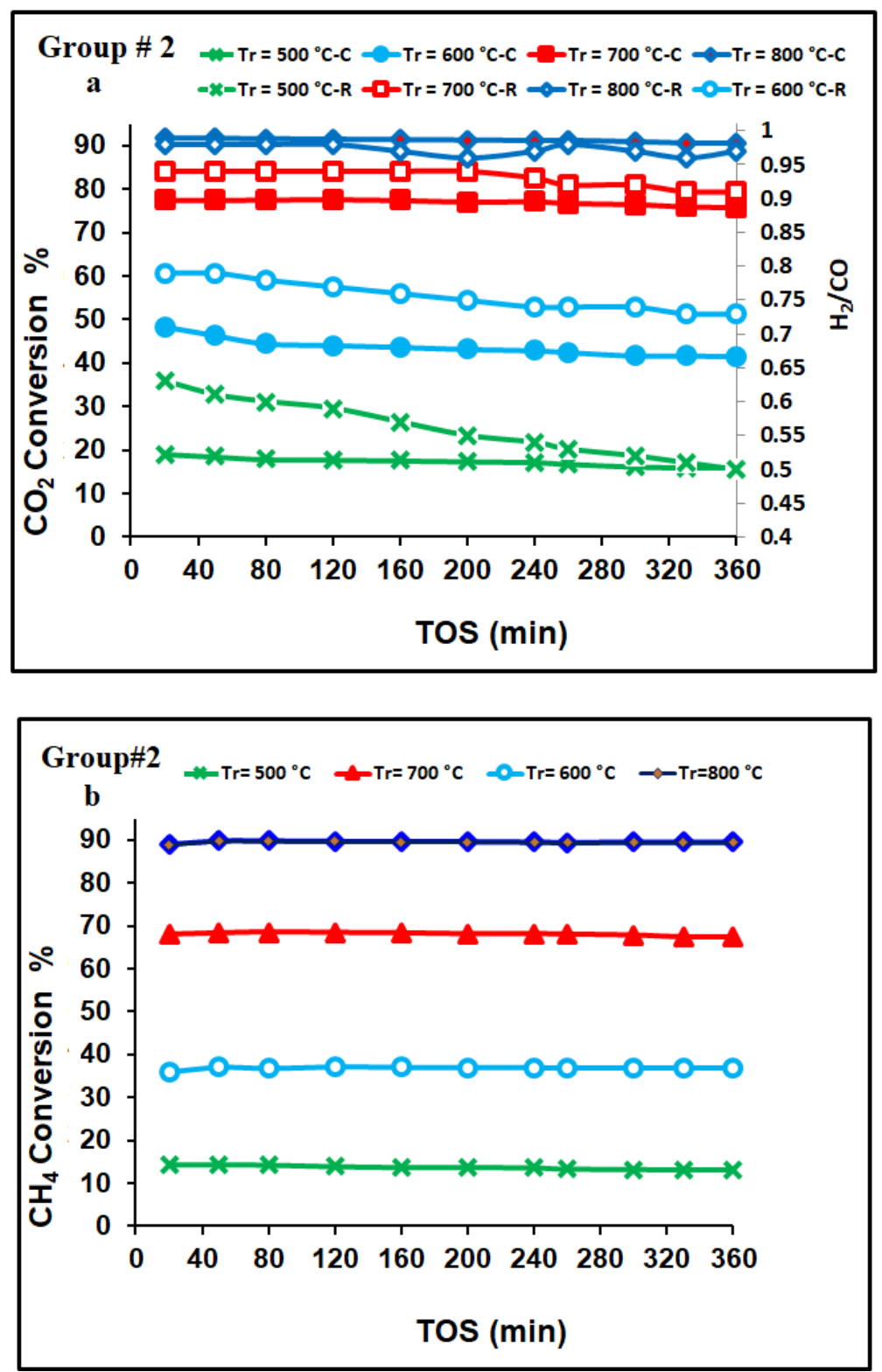

Fig. 14: course of a) $\mathrm{CO}_{2}$ conversion and $\mathrm{H}_{2} / \mathrm{CO}$ ratio and b) $\mathrm{CH}_{4}$ conversion with time on stream over CoNi-2 at reaction temperatures of $500-800{ }^{\circ} \mathrm{C}$, atmospheric pressure, $\mathrm{CH}_{4} / \mathrm{CO}_{2}=1: 1$, catalyst weight $=150 \mathrm{mg}, \mathrm{WHSV}=18000 \mathrm{ml} \cdot \mathrm{g}^{-1} \cdot \mathrm{h}^{-1}$. 

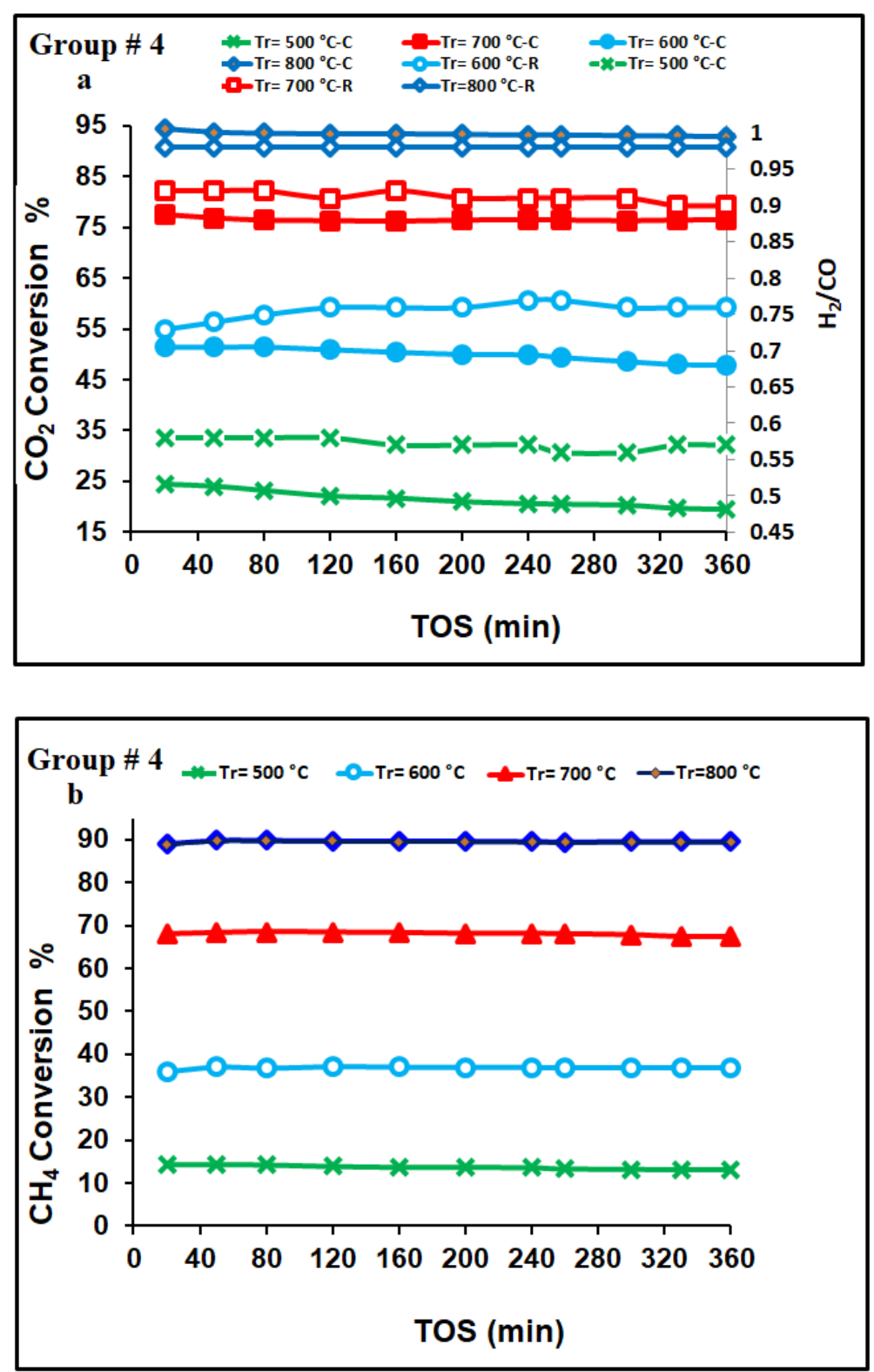

Fig. 15: course of a) $\mathrm{CO}_{2}$ conversion and $\mathrm{H}_{2} / \mathrm{CO}$ ratio and b) $\mathrm{CH}_{4}$ conversion with time on stream over CoNi-4 at reaction temperature of $500-800{ }^{\circ} \mathrm{C}$, atmospheric pressure, $\mathrm{CH}_{4} / \mathrm{CO}_{2}$ $=1: 1$. Catalyst was reduced in $\mathrm{H}_{2}$ at $800{ }^{\circ} \mathrm{C}$, catalyst weight $=150 \mathrm{mg}$, WHSV $=18000$ $\mathrm{ml} \cdot \mathrm{g}^{-1} \cdot \mathrm{h}^{-1}$.

To distinguish the nature of coke deposits formed at different reaction temperature, a TGA study for spent catalysts after $6 \mathrm{~h}$ on stream was conducted (Figures 10 and 11). Coke deposition over $\mathrm{CoNi}-4$ was less than for $\mathrm{CoNi}-2$ at all reaction temperatures, as $\mathrm{Co}$ and $\mathrm{Ni}$ were better dispersed on the surface of the support due to the strong interaction as it has 
been confirmed by TPR. In addition, it possesses the highest pore diameter due to hightemperature pre-treatment of the catalyst $[28,29]$. For CoNi-4 (Figure 11), the weight losses are $5,13,15$ and $30 \%$ at $800,700,500$ and $600{ }^{\circ} \mathrm{C}$, respectively. Moreover, for both catalysts CoNi-2 (Figure 10) and CoNi-4 (Figure 11) the lowest coke deposition rate was observed at $800{ }^{\circ} \mathrm{C}$. This can be attributed to the fact that the Boudouard reaction (Eq. 4) is exothermic and becomes thermodynamically less favourable above 700 ${ }^{\circ} \mathrm{C}[45,37,50]$. Moreover, at $800{ }^{\circ} \mathrm{C}$ the presence of zirconia in the support suppresses the methane decomposition (Eq. 3) and also promotes the reverse Boudouard reaction [5]. The highest amounts of coke deposits were measured at $600{ }^{\circ} \mathrm{C}$, as this intermediate temperature allows both methane decomposition (Eq. 3) and Boudouard reaction (Eq. 4) in remarkable extent [45].

Regarding the activity, CoNi-4 showed high $\mathrm{CH}_{4}$ conversion of $91 \%$ without deactivation and a $\mathrm{H}_{2} / \mathrm{CO}$ ratio of 0.96 at $800{ }^{\circ} \mathrm{C}$ and therefore it was chosen for further long-term tests (28 h on stream at $800{ }^{\circ} \mathrm{C}$ ), and the courses of $\mathrm{H}_{2} / \mathrm{CO}$ ratio, $\mathrm{CO}_{2}$ and $\mathrm{CH}_{4}$ conversion are presented in Figure 16. The catalyst showed only minor loss of its activity after $24 \mathrm{~h}$. However, with ongoing test, sharp drops in $\mathrm{CH}_{4}$ and $\mathrm{CO}_{2}$ conversion from $88.8 \%$ to $84 \%$ and from $94 \%$ to $80 \%$, respectively, were observed (relative loss of initial activity: 5\% in $\mathrm{CH}_{4}, 15 \%$ in $\mathrm{CO}_{2}$ ). The main cause of deactivation is carbon deposition as confirmed by TEM (Figure 12), TPO (Figure 13) and XRD (Figure 2) studies with the spent catalyst. 

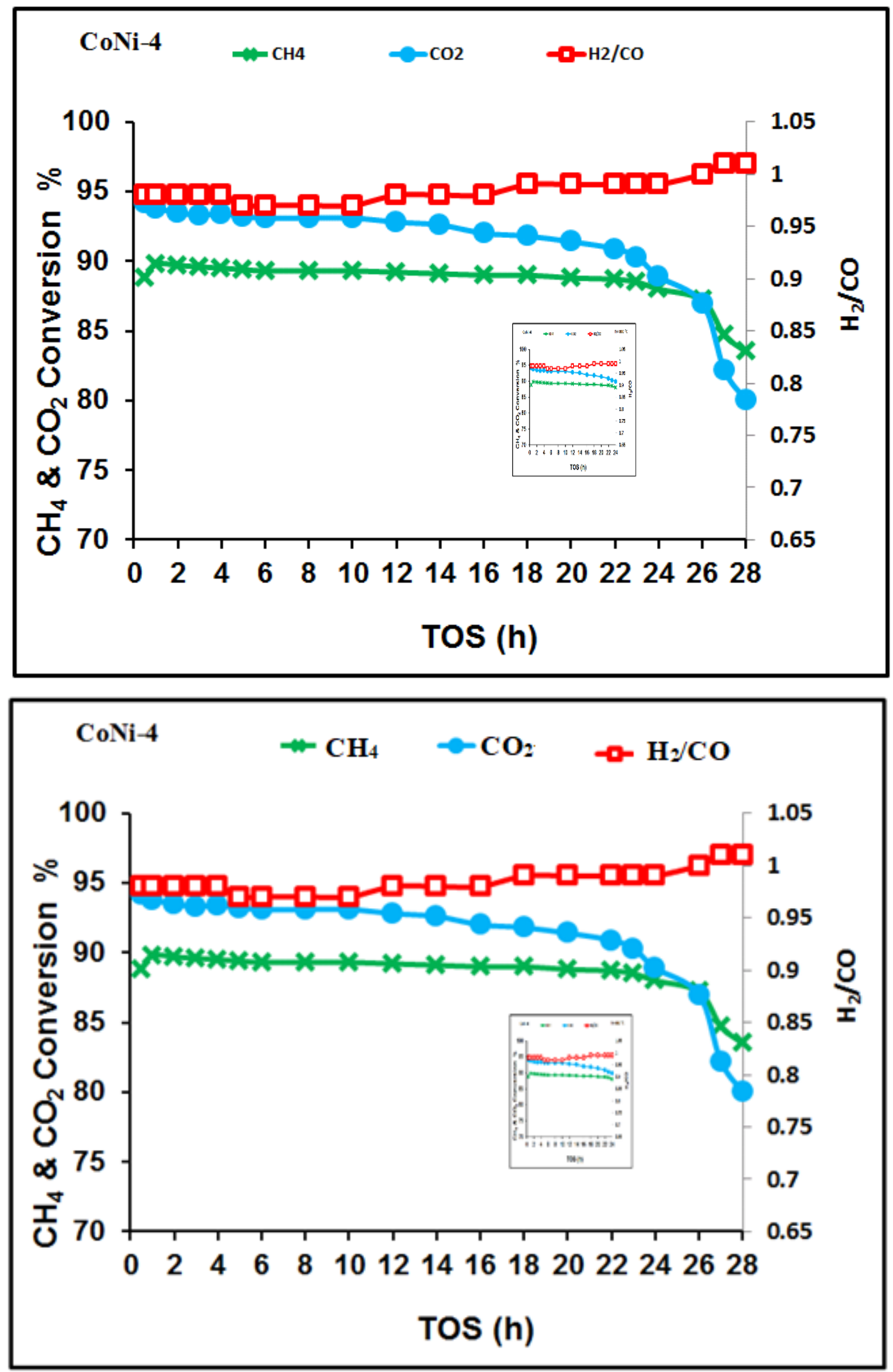
Fig. 16: long-term stability of CoNi-4 catalyst at $800{ }^{\circ} \mathrm{C}$, atmospheric pressure, $\mathrm{CH}_{4} / \mathrm{CO}_{2}$ $=1: 1$. Catalyst was reduced in $\mathrm{H}_{2}$ at $800{ }^{\circ} \mathrm{C}$, catalyst weight $=150 \mathrm{mg}$, WHSV $=18000$ $\mathrm{ml} \cdot \mathrm{g}^{-1} \cdot \mathrm{h}^{-1}$.

The addition of steam or oxygen to the feed thermodynamically suppresses the coke formation [51]. An increase of the methane conversion with steam addition has been reported in literature [52-54]. Moreover, steam acts as an oxidant removing carbon species from the surface of the catalyst [55]. It is well known that in the presence of a small amount of steam a higher stability of DRM catalysts and a $\mathrm{H}_{2} / \mathrm{CO}$ ratio close to unity are obtainable due to the WGS side reaction [53, 54]. In the present study, addition of small amounts of steam or oxygen to the feed has been tested as a way to increase the stability of the CoNi4 catalyst. The resulting course of $\mathrm{CH}_{4}$ conversion for $\mathrm{CO}_{2}$ reforming of methane at 700 ${ }^{\circ} \mathrm{C}$ is compared to conventional DRM in Figure 17. This particular catalyst lost around 9.4\% of initial activity in DRM, but only $5.4 \%$ in presence of water and only $3.2 \%$ in presence of $\mathrm{O}_{2}$. 

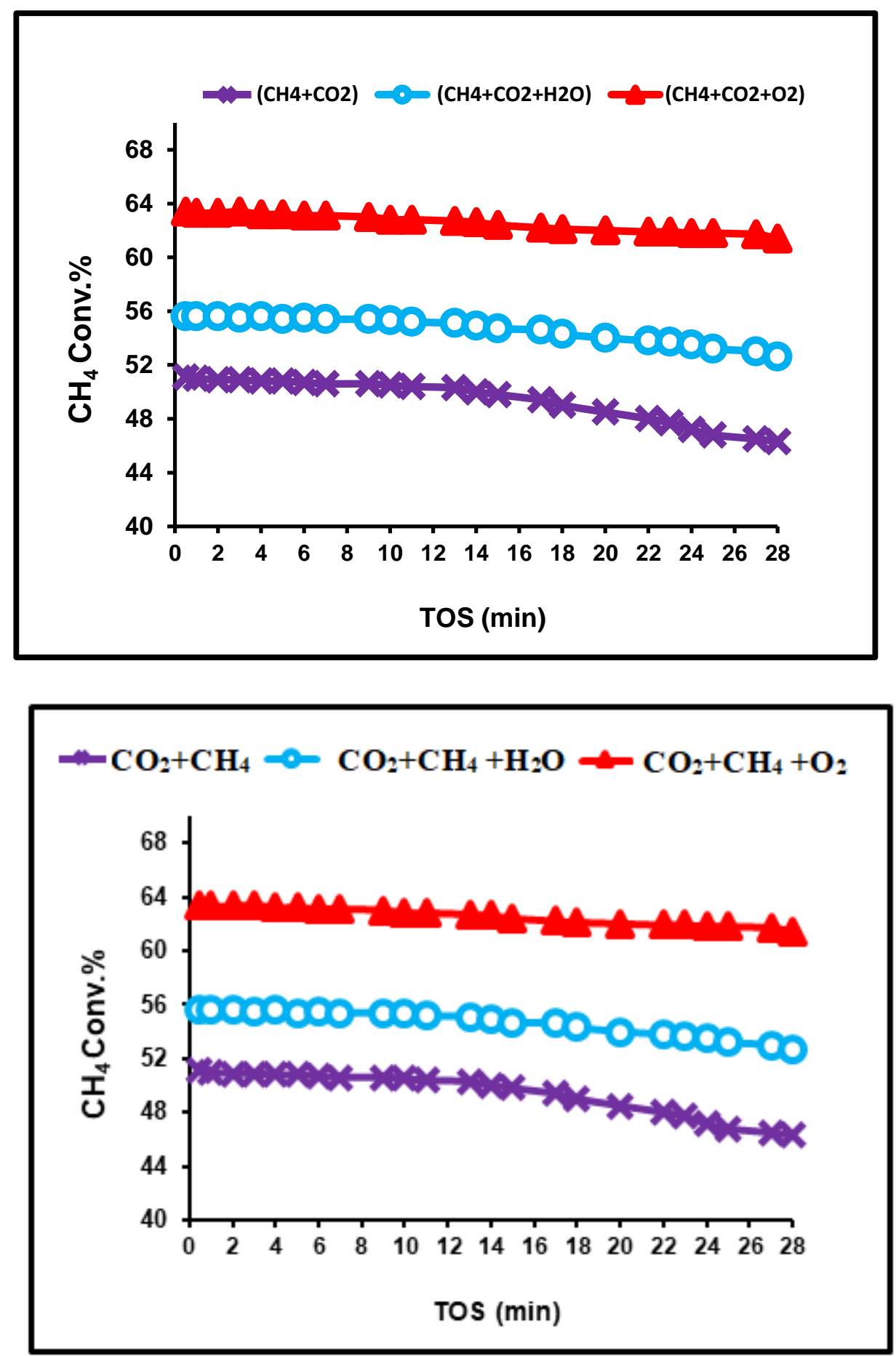

Fig. 17: Effect of steam or oxygen addition on long-term stability of CoNi-4 catalyst at $700{ }^{\circ} \mathrm{C}$, atmospheric pressure, catalyst was reduced in $\mathrm{H}_{2}$ at $800{ }^{\circ} \mathrm{C}$, catalyst weight $=$ $100 \mathrm{mg}$. 
TGA of spent CoNi-4 catalyst was conducted afterwards (Figure 18). The amount of carbon deposits decreased with the addition of a small amount of water or oxygen, which is in agreement with the catalyst stability (Figure 17).

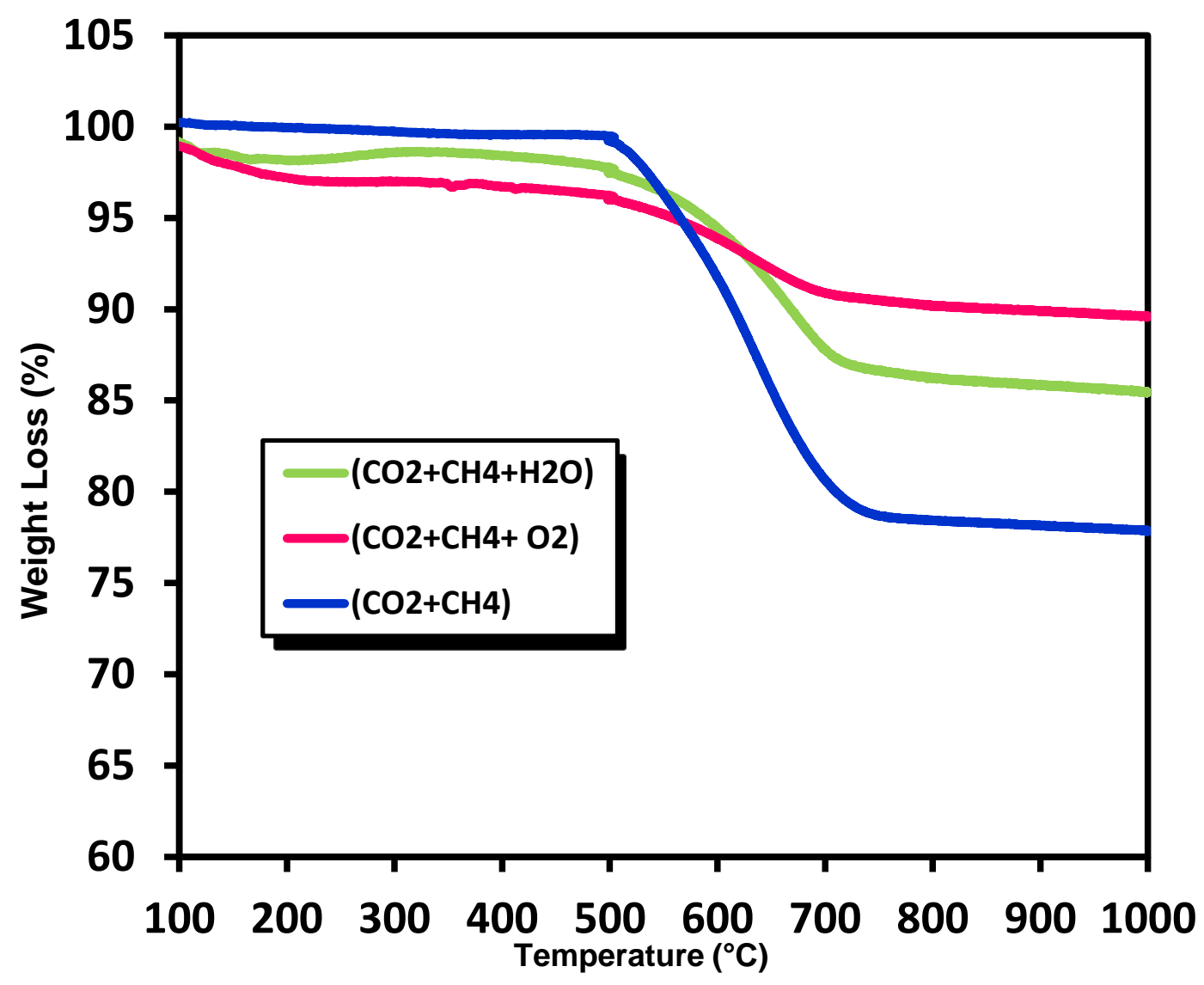




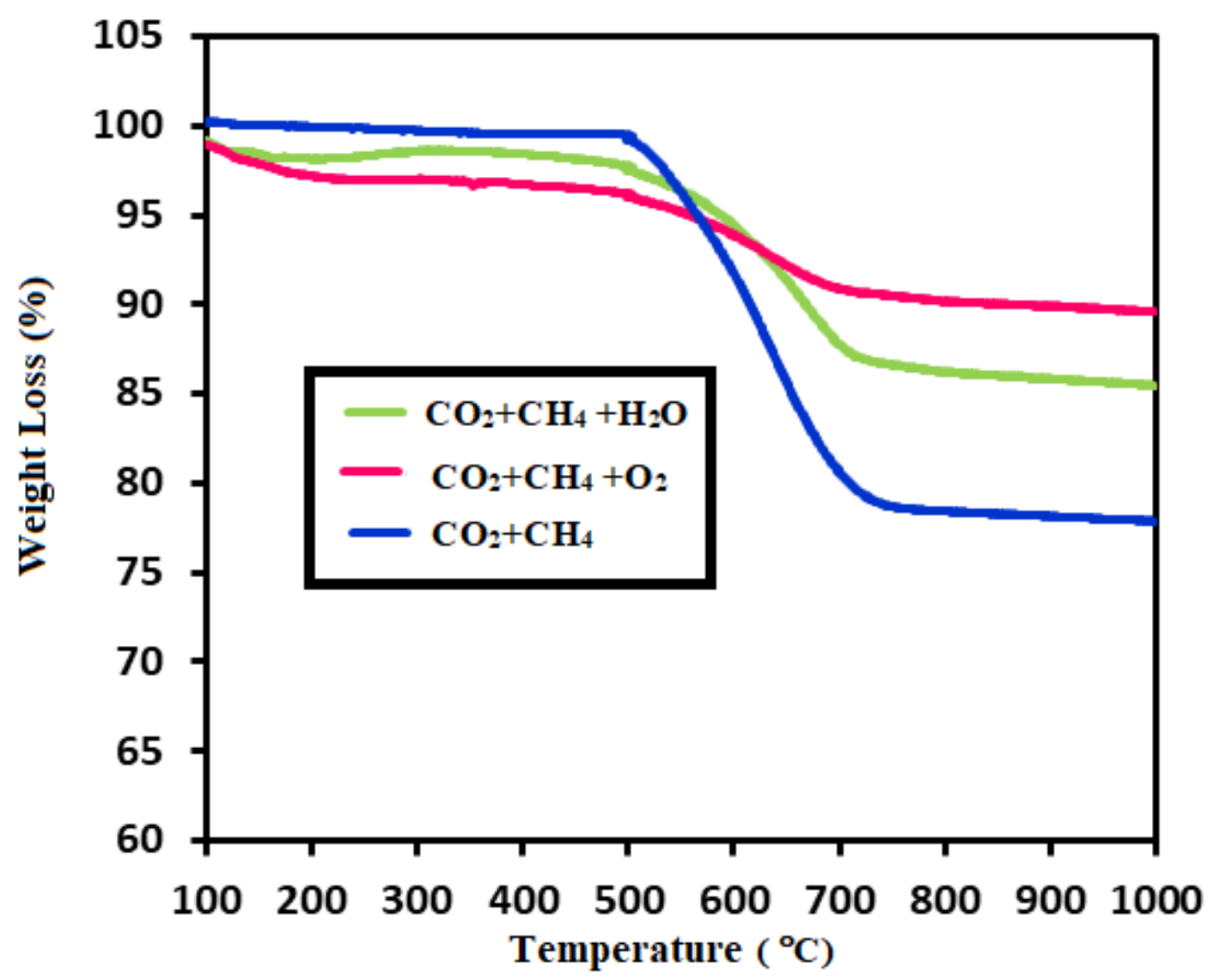

Fig. 18: TGA curves for spent $\mathrm{CoNi}-4$ catalysts used with different feeds at $700^{\circ} \mathrm{C}$, measured in $\mathrm{N}_{2}$ atmosphere with heating rate of $20 \mathrm{~K} / \mathrm{min}$.

\section{Conclusions}

Various monometallic and bimetallic catalysts supported on $\mathrm{Al}_{2} \mathrm{O}_{3}-\mathrm{ZrO}_{2}(\mathrm{Co}, \mathrm{Ni}$ and bimetallic $\mathrm{Co}-\mathrm{Ni}$ ) at different calcination and pre-treatment temperatures were tested for dry reforming of methane. The pre-treatment improved the catalytic performance and bimetallic catalysts outperformed the monometallic catalysts mainly due to synergy between both $\mathrm{Ni}$ and $\mathrm{Co}$. Interestingly the higher conversions resulted in higher carbon deposition which played significant role in catalyst deactivation. The least carbon deposition was observed on bimetallic CoNi-4 catalyst calcined under air at $800{ }^{\circ} \mathrm{C}$ and 
operated at $800{ }^{\circ} \mathrm{C}$ after $6 \mathrm{~h}$ on stream. This means that high calcination temperature triggers sintering and reduction of surface area and thus particle growth which in turn has an impact on the stability of the catalyst. As it has been reported, this catalyst showed high stability at these conditions for $28 \mathrm{~h}$ on stream. The deactivation is assigned to carbon deposition and was confirmed by XRD, TEM and TPO data. The catalyst stability was improved when steam or oxygen were added in the feed stream.

\section{Acknowledgment}

The authors would like to express their sincere appreciation to the Deanship of Scientific Research at King Saud University for funding this research project (\# RG-1435-078).

\section{References}

[1] Khani Y, Shariatinia Z and Bahadoran F. High catalytic activity and stability of $\mathrm{ZnLaAlO}_{4}$ supported $\mathrm{Ni}, \mathrm{Pt}$ and $\mathrm{Ru}$ nanocatalysts applied in the dry, steam and combined dry-steam reforming of methane. Chem. Eng. J. 2016;299: 353-366.

[2] Yang H, Xu Z, Fan M, Gupta R, Slimane RB, Bland AE and Wright I, Progress in carbon dioxide separation and capture: A review. J. Environ. Sci. 2008; 20: 14-27.

[3] Sumrunronnasak S, Tantayanon S, Kiatgamolchai S and Sukonket T, Improved hydrogen production from dry reforming reaction using a catalytic packed-bed membrane reactor with Ni-based catalyst and dense PdAgCu alloy membrane. Int. J. Hydrogen Ener. 2016; 41: 2621-2630.

[4] Usman M, Wan Daud WMA and Abbas HF, Dry reforming of methane: Influence of process parameters- A review. Renew. and Sust. Energ. Rev. 2015; 45: 710-744. 
[5] Perez-Camacho MN, Abu-Dahrieh J, Goguet A, Sun K and Rooney D, Selfcleaning perovskite type catalysts for the dry reforming of methane. Chin. J. Catal. 2014; 35: 1337-1346.

[6] Perez-Camacho MN, Abu-Dahrieh J, Rooney D and Sun K, Biogas reforming using renewable wind energy and induction heating. Catal. Today 242, Part A: 2015; 129-138.

[7] Charisiou ND, Siakavelas G, Papageridis KN, Baklavaridis A, Tzounis L, Avraam DG and Goula MA, Syngas production via the biogas dry reforming reaction over nickel supported on modified with $\mathrm{CeO}_{2}$ and/or $\mathrm{La}_{2} \mathrm{O}_{3}$ alumina catalysts. J. Nat. Gas Sci. Eng. 2016; 31: 164-183.

[8] Niu J, Du X, Ran J and Wang R, Dry $\left(\mathrm{CO}_{2}\right)$ reforming of methane over Pt catalysts studied by DFT and kinetic modeling. Appl. Surf. Sci. 2016; 376: 79-90.

[9] Chengyun Z, Cui L, Danlian H, Guangming Z, Chen Z, Min C, Liang H, Jia W, Weiping X, Ming W, Xiaofeng W, Lei Q, Highly porous carbon nitride by supramolecular preassembly of monomers for photocatalytic removal of sulfamethazine under visible light driven. Appl. Catal. B: Environ. 2018; 220: 202-210.

[10] Yang Y, Chen Z, Danlian H, Guangming Z, Jinhui H, Cui L, Chengyun Z, Wenjun W, Hai G, Wenjing X, Rui D, Min C, Weiping X, Boron nitride quantum dots decorated ultrathin porous $\mathrm{g}-\mathrm{C}_{3} \mathrm{~N}_{4}$ : Intensified exciton dissociation and charge transfer for promoting visible-light-driven molecular oxygen activation. Appl. Catal. B: Environ. 2019; 245: 8799.

[11] Chengyun Z, Cui L, Chen Z, Guangming Z, Danlian H, Min C, Liang H, Weiping X, Ming C, Jiajia W, Yang Y, Longbo J, Semiconductor/boron nitride composites: 
Synthesis, properties, and photocatalysis applications. Appl. Catal. B: Environ. 2018; 238: 6-18.

[12] Chengyun Z, Cui L, Piao X, Guangming Z, Danlian H, Zhihao L, Chen Z, Min C, Liang H, Jia W, Fei C, Weiping X, Rui D, Rational Design of Carbon-Doped Carbon Nitride/ $\mathrm{Bi}_{12} \mathrm{O}_{17} \mathrm{Cl}_{2}$ Composites: A Promising Candidate Photocatalyst for Boosting Visible-Light-Driven Photocatalytic Degradation of Tetracycline. ACS Sustain. Chem. Eng. 2018; 6: 6941-6949.

[13] Xiang R, Ruixiang G, Yong Z, Danni L, Dan W, Xu S, Bin D, Qin W, Cobaltborate nanowire array as a high-performance catalyst for oxygen evolution reaction in nearneutral media. J. Mater. Chem. A 2017; 5: 7291-7294.

[14] Xiang R, Dan W, Ruixiang G, Xu S, Hongmin M, Tao Y, Yong Z, Bin D, Qin W, Liang C, Self-supported $\mathrm{CoMoS}_{4}$ nanosheet array as an efficient catalyst for hydrogen evolution reaction at neutral pH. Nano Res. 2018; 11: 2024-2033.

[15] Xiang R, Xuqiang J, Yicheng W, Dan W, Yong Z, Min M, Zhiang L, Abdullah MA, Qin W, Xuping S, In situ electrochemical development of copper oxide nanocatalysts within a TCNQ nanowire array: a highly conductive electrocatalyst for the oxygen evolution reaction. Chem. Comm. 2018; 54: 1425-1428.

[16] Jinxiu Z, Xiang R, Qingzhi H, Dawei F, Xu S, Xuan K, Qin W, Dan W, Ultra-thin wrinkled $\mathrm{NiOOH}-\mathrm{NiCr}_{2} \mathrm{O}_{4}$ nanosheets on $\mathrm{Ni}$ foam: an advanced catalytic electrode for oxygen evolution reaction. Chem. Comm. 2018; 54: 4987-4990.

[17] Jinxiu Z, Xiang R, Hongmin M, Xu S, Yong Z, Tao Y, Qin W, Dan W, Synthesis of Self-Supported Amorphous $\mathrm{CoMoO}_{4}$ Nanowire Array for Highly Efficient Hydrogen Evolution Reaction. ACS Sustain. Chem. Eng. 2017; 5: 10093-10098. 
[18] Benrabaa R, Lofberg A, Rubbens A, Bordes-Richard E, Vannier RN and Barama A, Structure, reactivity and catalytic properties of nanoparticles of nickel ferrite in the dry reforming of methane. Catal. Today 2013; 203: 188-195.

[19] Hao Z, Zhu Q, Jiang Z, Hou B and Li H, Characterization of aerogel Ni/ $\mathrm{Al}_{2} \mathrm{O}_{3}$ catalysts and investigation on their stability for $\mathrm{CH} 4-\mathrm{CO} 2$ reforming in a fluidized bed. Fuel Process Technol. 2009; 90: 113-121.

[20] Luengnaruemitchai A and Kaengsilalai A, Activity of different zeolite-supported Ni catalysts for methane reforming with carbon dioxide. Chem. Eng. J. 2008; 144: 96-102. [21] Pompeo F, Nichio NN, Gonzalez MG and Montes $\mathrm{M}$, Characterization of $\mathrm{Ni} / \mathrm{SiO}_{2}$ and $\mathrm{Ni} / \mathrm{Li}-\mathrm{SiO}_{2}$ catalysts for methane dry reforming. Catal. Today 2005; 107-108: 856-862. [22] Fakeeha AH, Khan WU, Al-Fatesh AS and Abasaeed AE, Stabilities of zeolitesupported Ni catalysts for dry reforming of methane. Chin. J. Catal. 2013; 34: 764-768.

[23] Xiang X, Zhao H, Yang J, Zhao J, Yan L, Song H and Chou L, Nickel based mesoporous silica-ceria-zirconia composite for carbon dioxide reforming of methane. Appl. Catal. A: G 2016; 520: 140-150.

[24] Albarazi A, Galvez ME and Da Costa P, Synthesis strategies of ceria-zirconia doped Ni/SBA-15 catalysts for methane dry reforming. Catal. Comm. 2015; 59: 108-112. [25] Wolfbeisser A, Sophiphun O, Bernardi J, Wittayakun J, Fottinger K and Rupprechter G, Methane dry reforming over ceria-zirconia supported Ni catalysts. Catal. Today in press 2016; 277: 234-245.

[26] Rahemi N, Haghighi M, Babaluo AA, Jafari MF and Estifaee P, Synthesis and physicochemical characterizations of $\mathrm{Ni} / \mathrm{Al}_{2} \mathrm{O}_{3}-\mathrm{ZrO}_{2}$ nanocatalyst prepared via 
impregnation method and treated with non-thermal plasma for $\mathrm{CO}_{2}$ reforming of $\mathrm{CH}_{4} . \mathrm{J}$. Ind. Eng. Chem. 2013; 19: 1566-1576.

[27] Bellido JDA, De Souza JE, MPeko J-C and Assaf EM, Effect of adding CaO to $\mathrm{ZrO}_{2}$ support on nickel catalyst activity in dry reforming of methane. Appl. Catal. A: G 2009; 358: 215-223.

[28] Al-Fatesh ASA and Fakeeha AH, Effects of calcination and activation temperature on dry reforming catalysts. J. S. Chem. Soc. 2012; 16: 55-61.

[29] Rezgui Y and Guemini M, Effect of pretreatment conditions on the catalytic performance of Ni-Pt-W supported on amorphous silica-alumina catalysts: Part 1. Catalysts prepared by a sol-gel method. Appl. Catal. A: General 335: 103-111 (2008).

[30] Chen L, Lu Y, Hong Q, Lin J and Dautzenberg FM, Catalytic partial oxidation of methane to syngas over Ca-decorated- $\mathrm{Al}_{2} \mathrm{O}_{3}$-supported $\mathrm{Ni}$ and $\mathrm{NiB}$ catalysts. Appl. Catal. A: G 2005; 292: 295-304.

[31] Wang HY and Ruckenstein E, Conversions of Methane to Synthesis Gas over Co/ $\gamma$ $\mathrm{Al}_{2} \mathrm{O}_{3}$ by $\mathrm{CO}_{2}$ and/or $\mathrm{O}_{2}$. Catal. Lett. 2001; 75: 13-18.

[32] Sun H, Wang $\mathrm{H}$ and Zhang J, Preparation and characterization of nickel-titanium composite xerogel catalyst for $\mathrm{CO}_{2}$ reforming of $\mathrm{CH}_{4}$. Appl. Catal. B: Environ. 2007; 73: $158-165$.

[33] Al-Fatesh A, Suppression of carbon formation in $\mathrm{CH} 4-\mathrm{CO} 2$ reforming by addition of Sr into bimetallic Ni-Co/ $\gamma-\mathrm{Al}_{2} \mathrm{O}_{3}$ catalyst. J. K. S. U. - Eng. Sci. 2015; 27: 101-107. [34] Guo C, Hu P, Yu L and Yuan F, Synthesis and characterization of $\mathrm{ZrO}_{2}$ hollow spheres. Mater. Lett. 2009; 63: 1013-1015. 
[35] Kruglova MA and Yaroshenko MP, Preparation and characteristics of zirconiumaluminum oxide system. Russ J. Appl. Chem. 2007; 80: 1461-1467.

[36]. Zhang, J.; Wang, H.; Dalai, A. K. Development of stable bimetallic catalysts for carbon dioxide reforming of methane J. Catal. 2007, 249: 300-310.

[37] Osaki $\mathrm{T}$ and Mori $\mathrm{T}$, Kinetic studies of $\mathrm{CO}_{2}$ dissociation on supported Ni catalysts. React Kinet Catal. Lett. 2005; 87: 149-156.

[38] Zhu Z-Z, Wang $\mathrm{Z}$ and $\mathrm{Li}$ H-L, Functional multi-walled carbon nanotube/polyaniline composite films as supports of platinum for formic acid electrooxidation. Appl. Surf. Sci. 2008; 254: 2934-2940.

[39] Lu C, Su F and Hu S, Surface modification of carbon nanotubes for enhancing BTEX adsorption from aqueous solutions. Appl. Surf. Sci. 2008; 254: 7035-7041.

[40] Li ZQ, Lu CJ, Xia ZP, Zhou Y and Luo Z, X-ray diffraction patterns of graphite and turbostratic carbon. Carbon 2007; 45: 1686-1695.

[41] Singh KSW, Rouquerol J, Bergeret G, Gallezot P, Vaarkamp M, Koningsberger DC, Datye AK, Niemantsverdriet JW, Butz T, Engelhardt G, Mestl G, Knözinger H and Jobic H, Characterization of Solid Catalysts: Sections 3.1.1 - 3.1.3, in Handbook of Heterogeneous Catalysis. Wiley-VCH Verlag GmbH, pp. 427-582 2008.

[42] Matthew M. Yung, Erik M. Holmgreen, Umit S. Ozkan, Cobalt-based catalysts supported on titania and zirconia for the oxidation of nitric oxide to nitrogen dioxide. J. Catal. 2007; 247: 356-367.

[43] Al-Fatish ASA, Ibrahim AA, Fakeeha AH, Soliman MA, Siddiqui MRH and Abasaeed $\mathrm{AE}$, Coke formation during $\mathrm{CO}_{2}$ reforming of $\mathrm{CH} 4$ over alumina-supported nickel catalysts. Appl. Catal. A: G 2009; 364: 150-155. 
[44] Gonzalez-delaCruz VM, Pereniguez R, Ternero F, Holgado JP and Caballero A, In Situ XAS Study of Synergic Effects on $\mathrm{Ni}-\mathrm{Co} / \mathrm{ZrO}_{2}$ Methane Reforming Catalysts. J. Phys. Chem. C 116: 2012; 2919-2926.

[45] Zhang J, Wang H and Dalai AK, Effects of metal content on activity and stability of Ni-Co bimetallic catalysts for $\mathrm{CO}_{2}$ reforming of CH4. Appl. Catal. A: G 2008; 339: 121129.

[46] Arkatova LA, The deposition of coke during carbon dioxide reforming of methane over intermetallides. Catal. Today 2010; 157: 170-176.

[47] Kim JH, Suh DJ, Park TJ and Kim KL, Effect of metal particle size on coking during $\mathrm{CO}_{2}$ reforming of $\mathrm{CH}_{4}$ over Ni-alumina aerogel catalysts. Appl. Catal. A: G 2000; 197: 191-200.

[48] Xu Z, Li Y, Zhang J, Chang L, Zhou R and Duan Z, Bound-state Ni species - a superior form in Ni-based catalyst for $\mathrm{CH}_{4} / \mathrm{CO}_{2}$ reforming. Appl. Catal. A: G 2001; 210 : $45-53$.

[49] Kitiyanan B, Alvarez WE, Harwell JH and Resasco DE, Controlled production of single-wall carbon nanotubes by catalytic decomposition of $\mathrm{CO}$ on bimetallic $\mathrm{Co}-\mathrm{Mo}$ catalysts. Chem Phys Lett. 2000; 317: 497-503.hju

[50] Osaki $\mathrm{T}$ and Mori $\mathrm{T}$, Kinetics of the reverse-Boudouard reaction over supported nickel catalysts. React. Kinet. Catal. Lett. 2006; 89: 333-339.

[51] Wang W, Su C, Wu Y, Ran R and Shao Z, Progress in Solid Oxide Fuel Cells with Nickel-Based Anodes Operating on Methane and Related Fuels. Chem. Rev. 2013; 113: 8104-8151. 
[52] Soria MA, Mateos-Pedrero C, Guerrero-Ruiz A and Rodriguez-Ramos I, Thermodynamic and experimental study of combined dry and steam reforming of methane on $\mathrm{Ru} / \mathrm{ZrO}_{2}-\mathrm{La}_{2} \mathrm{O}_{3}$ catalyst at low temperature. Int. J. Hydrogen Ener. 2011; 36: 1521215220.

[53] O-zkara-Aydinoglu S, Thermodynamic equilibrium analysis of combined carbon dioxide reforming with steam reforming of methane to synthesis gas. Int. J. Hydrogen Ener. 2010; 35: 12821-12828.

[54] O-zkara-Aydinoglu $\mathrm{S}$ and Aksoylu $\mathrm{AE}, \mathrm{CO}_{2}$ reforming of methane over Pt$\mathrm{Ni} / \mathrm{Al}_{2} \mathrm{O}_{3}$ catalysts: Effects of catalyst composition, and water and oxygen addition to the feed. Int. J. Hydrogen Ener. 2011; 36: 2950-2959.

[55] Eltejaei H, Reza Bozorgzadeh H, Towfighi J, Reza Omidkhah M, Rezaei M, Zanganeh R, Zamaniyan A and Zarrin Ghalam A, Methane dry reforming on $\mathrm{Ni} / \mathrm{Ce}_{0.75} \mathrm{Zr}_{0.25} \mathrm{O}_{2}-\mathrm{MgAl}_{2} \mathrm{O}_{4}$ and $\mathrm{Ni} / \mathrm{Ce}_{0.75} \mathrm{Zr}_{0.25} \mathrm{O}_{2}-\gamma$-alumina: Effects of support composition and water addition. Int. J. Hydrogen Ener. 2011; 37: 4107-4118. 